\title{
Changes in Cytochemistry of Sensory and Nonsensory Cells in Gentamicin-Treated Cochleas
}

\author{
Shun-ICHi Imamura ${ }^{1}$ and Joe C. Adams ${ }^{2}$ \\ ${ }^{1}$ Department of Otolaryngology, Shinshu University School of Medicine, 3-1-1 Asahi, Matsumoto, Nagano 390-8621, Japan \\ ${ }^{2}$ Department of Otology and Laryngology, Harvard Medical School, Massachusetts Eye and Ear Infirmary, Boston, MA 02114, \\ USA
}

Received: 1 August 2001; Accepted: 14 October 2002; Online publication: 15 January 2003

\begin{abstract}
Effects of a single local dose of gentamicin upon sensory and nonsensory cells throughout the cochlea were assessed by changes in immunostaining patterns for a broad array of functionally important proteins. Cytochemical changes in hair cells, spiral ganglion cells, and cells of the stria vascularis, spiral ligament, and spiral limbus were found beginning 4 days post administration. The extent of changes in immunostaining varied with survival time and with cell type and was not always commensurate with the degree to which individual cell types accumulated gentamicin. Outer hair cells, types I and II fibrocytes of the spiral ligament, and fibrocytes in the spiral limbus showed marked decreases in immunostaining for a number of constituents. In contrast, inner hair cells, type III fibrocytes and root cells of the spiral ligament, cells of the stria vascularis, and interdental cells in the spiral limbus showed less dramatic decreases, and in some cases they showed increases in immunostaining. Results indicate that, in addition to damaging sensory cells, local application of gentamicin results in widespread and disparate disruptions of a variety of cochlear cell types. Only in the case of ganglion cells was it apparent that the changes in nonsensory cells were secondary to loss or damage of hair cells. These results indicate that malfunction of the ear following gentamicin treatment is widespread and far more complex than simple loss of sensory elements. The results have implications for efforts directed toward
\end{abstract}

Correspondence to: Joe C. Adams - Department of Otolaryngology • Massachusetts Eye and Ear Infirmary $\cdot 243$ Charles Street - Boston, MA 02114. Telephone: (617) 573-3975; fax: (617) 720-4408; email: jadams@meei.harvard.edu detecting, preventing, and treating toxic effects of aminoglycosides upon the inner ear.

Keywords: aminoglycoside toxicity, spiral ligament, organ of Corti, immunostaining

\section{INTRODUCTION}

Many of the morphological and physiological changes that occur within the cochlea following aminoglycoside drug application are well known (Davis et al. 1958; Mendelsohn and Katzenberg 1972; Konishi 1979; Hawkins and Johnsson 1981; Komune and Snow 1982; Forge and Fradis 1985; Kimura et al. 1988, 1991; DeGroot et al. 1991). Current clinical use of aminoglycosides for treatment of vertigo patients has prompted further study of the cellular mechanisms involved in aminoglycoside ototoxicity (see reviews by Wersall 1995; Forge and Schacht 2000; Nakashima et al. 2000). The mechanisms underlying cochlear dysfunction following aminoglycoside application are not yet completely understood. Physiological changes, including reduction of the endocochlear potential and cochlear microphonics, and changes in endolymphatic ionic composition following aminoglycoside treatment have been investigated (Mendelsohn and Katzenberg 1972; Konishi 1979; Komune and Snow 1982). It seems unlikely that all of the reported effects could be directly attributed to loss of hair cells. Morphological alterations of hair cells using light and electron microscope have also been studied extensively (Davis et al. 1958; Hawkins and Johnsson 1981; Forge and Fradis 1985; 
TABLE 1

Sources, dilutions, and characterizations of antibodies used in this study.

\begin{tabular}{|c|c|c|c|c|c|}
\hline Antibodies & Source & Host & Dilution & Specificity & Positive control \\
\hline $\begin{array}{l}\mathrm{Na}^{+}, \mathrm{K}^{+}-\mathrm{ATPase} \\
\text { (ATPase) }\end{array}$ & $\begin{array}{l}\text { Courtesy of } \\
\text { Dr. George } \\
\text { Siegel }\end{array}$ & Rabbit & $1: 300 \mathrm{~K}$ & $\begin{array}{l}\text { Bovine } \\
\text { cortex } \\
\mathrm{Na}^{+}, \mathrm{K}^{+} \text {-ATPase }\end{array}$ & Brain \\
\hline $\begin{array}{l}\mathrm{Na}^{+}, \mathrm{Ca}^{++} \\
\text {exchanger } \\
(\mathrm{NaCaX})\end{array}$ & SWant ${ }^{b}$ & Rabbit & $1: 10 \mathrm{~K}$ & $\begin{array}{l}\text { Cardiac } \\
\mathrm{Na}^{+}, \mathrm{Ca}^{++} \\
\text {exchanger }\end{array}$ & Heart \\
\hline $\begin{array}{l}\text { Carbonic } \\
\text { anhydrase } \\
\text { (CA) }\end{array}$ & Biodesign $^{c}$ & Rabbit & $1: 100 K$ & $\begin{array}{l}\text { Bovine red } \\
\text { blood cell } \\
\text { carbonic } \\
\text { anhydrase }\end{array}$ & Erythrocytes \\
\hline $\begin{array}{l}\text { Creatine kinase } \\
\quad(\mathrm{CKBB})\end{array}$ & Ventrex $^{d}$ & Rabbit & $1: 30 \mathrm{~K}$ & $\begin{array}{l}\text { Human creatine } \\
\text { kinase isozyme } \\
\text { BB }\end{array}$ & Brain \\
\hline PMCA & $\begin{array}{l}\text { Affinity } \\
\text { BioReagents }\end{array}$ & Mouse & $1: 20 \mathrm{~K}$ & $\begin{array}{l}\mathrm{Ca}^{++} \text {pump of } \\
\text { the plasma } \\
\text { membrane }\end{array}$ & Choroid plexus \\
\hline SERCA1 ATPase & $\begin{array}{l}\text { Affinity } \\
\text { Bioreagents }\end{array}$ & Mouse & $1: 5 \mathrm{~K}$ & $\begin{array}{l}\text { ATPase- } \\
\text { dependent } \\
\text { calcium pump } \\
\text { in type II } \\
\text { skeletal muscle }\end{array}$ & Muscle \\
\hline SERCA2 ATPase & $\begin{array}{l}\text { Affinity } \\
\text { Bioreagents }\end{array}$ & Mouse & $1: 5 \mathrm{~K}$ & $\begin{array}{l}\text { ATPase- } \\
\text { dependent } \\
\text { calcium pump } \\
\text { in type I } \\
\text { skeletal muscle }\end{array}$ & Muscle \\
\hline $\begin{array}{l}\text { Connexin } 26 \\
(\mathrm{C} \times 26)\end{array}$ & $\begin{array}{l}\text { Courtesy of } \\
\text { Dr. David } \\
\text { Paul }^{f}\end{array}$ & Rabbit & $1: 30 \mathrm{~K}$ & $\begin{array}{l}\text { Gap junction } \\
\text { protein in } \\
\text { rat liver and skin }\end{array}$ & Skin \\
\hline $\begin{array}{l}\text { Vimentin } \\
\quad(\text { Vim) }\end{array}$ & Biogenex ${ }^{g}$ & Mouse & $1: 600 \mathrm{~K}$ & $\begin{array}{l}57 \mathrm{kD} \\
\text { intermediate } \\
\text { filament vimentin }\end{array}$ & Blood vessels \\
\hline $\begin{array}{l}\text { 200kD } \\
\text { neurofilaments } \\
\text { (NF) }\end{array}$ & Boehringer $^{\mathrm{h}}$ & Mouse & $1: 50 \mathrm{~K}$ & $\begin{array}{l}200 \mathrm{kD} \\
\text { neurofilaments } \\
\text { in rat brain }\end{array}$ & Brain \\
\hline $\begin{array}{l}\text { Peptide } 19 \\
\text { (Pep19) }\end{array}$ & $\begin{array}{l}\text { Courtesy of } \\
\text { Dr. James } \\
\text { Morgan }^{i}\end{array}$ & Rabbit & $1: 20 \mathrm{~K}$ & Synthetic peptide & Cerebellum \\
\hline $\begin{array}{l}\text { Calbindin } \\
\text { (CaBP) }\end{array}$ & Sigma $^{\mathrm{j}}$ & Mouse & $1: 30 \mathrm{~K}$ & $\begin{array}{l}\text { Calbindin 28KD } \\
\text { from guinea } \\
\text { pig brain }\end{array}$ & Cerebellum \\
\hline $\begin{array}{l}\text { Calretinin } \\
\quad(\mathrm{CaR})\end{array}$ & $\begin{array}{l}\text { Courtesy of } \\
\text { Dr. Lois } \\
\text { Winsky }\end{array}$ & Rabbit & $1: 60 \mathrm{~K}$ & $\begin{array}{l}\text { Calretinin from } \\
\text { guinea pig brain }\end{array}$ & Superior olive \\
\hline $\begin{array}{l}\text { Calmodulin } \\
\text { (CaM) }\end{array}$ & $\mathrm{UBI}^{\mathrm{I}}$ & Mouse & $1: 2 \mathrm{M}$ & $\begin{array}{l}\text { Bovine } \\
\mathrm{Ca}^{++}-\text {bound } \\
\text { and } \mathrm{Ca}^{++} \text {-free } \\
\text { calmodulin }\end{array}$ & Cerebellum \\
\hline S-100 & Sigmab $^{\mathrm{b}}$ & Rabbit & $1: 3 \mathrm{M}$ & $\begin{array}{l}\text { S-100 from } \\
\text { bovine brain }\end{array}$ & Inferior colliculus \\
\hline $\begin{array}{l}\text { Caldesmon } \\
\text { (CaD) }\end{array}$ & Sigma $^{b}$ & Mouse & $1: 30 \mathrm{~K}$ & $\begin{array}{l}\text { Chicken gizzard } \\
\text { caldesmon }\end{array}$ & Smooth muscle \\
\hline
\end{tabular}

Kimura et al. 1988, 1991; Bareggi et al. 1990; DeGroot et al. 1991; Husmann et al. 1998; Wanamaker et al. 1999). However, little attention has been given to the effects of aminoglycosides upon nonsensory cells. In the accompanying article it was shown that, following a single application, most cochlear cells accumulate gentamicin and some cells remain immunoreactive for gentamicin for extended periods. In the present report some of the cytochemical consequences of gentamicin administration upon sensory and nonsensory cells are examined using immunocytochemistry to examine a broad range of functionally diverse proteins. The experimental design included only animals that received a single unilateral application 


\begin{tabular}{|c|c|c|c|c|c|}
\hline \multicolumn{6}{|c|}{ TABLE 1} \\
\hline \multicolumn{6}{|c|}{ Continued } \\
\hline $\begin{array}{l}\text { Osteopontin } \\
\text { (OPN) }\end{array}$ & $\begin{array}{l}\text { Courtesy of } \\
\text { Dr. Robin } \\
\text { Davis }\end{array}$ & Rabbit & $1: 5 \mathrm{~K}$ & $\begin{array}{l}\text { C-terminal segment } \\
\text { of mouse osteopontin }\end{array}$ & Bone \\
\hline $\begin{array}{l}\text { IP } P_{3} \text {-receptor } \\
\quad\left(I P_{3} R\right)\end{array}$ & $\begin{array}{l}\text { Courtesy of } \\
\text { Dr. DeCamilli }\end{array}$ & Rabbit & $1: 10 \mathrm{~K}$ & Synthetic peptide & Cerebellum \\
\hline
\end{tabular}

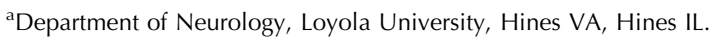

${ }^{\mathrm{b}}$ Swiss antibodies, Bellinzona, Switzerland.

${ }^{\mathrm{c} B i o d e s i g n}$ International, Inc., Kennebunkport, ME.

dVentrex Laboratories, Inc., Portland, ME.

${ }^{\mathrm{e}}$ Affinity BioReagents, Neshanic Station, NJ.

fDepartment of Neurobiology, Harvard Medical School, Boston, MA.

${ }^{\mathrm{g}}$ Biogenex Laboratories San Ramon, CA.

${ }^{\text {h}}$ Boehringer Mannheim Biochemicals. Indianapolis, IN.

iSt. Jude Children's Research Hospital, Memphis, TN.

'Sigma Chemical Co., St. Louis, MO.

kLaboratory of Clinical Science and Clinical NeuroScience Branch, National Institute of Mental Health, Bethesda, MD.

'Upstate Biotechnology, Inc., Lake Placid, NY.

${ }^{\mathrm{m}}$ Department of Biological Science, Rutgers University, Piscataway, NJ.

${ }^{\mathrm{n} D e p a r t m e n t ~ C e l l ~ B i o l o g y ~ a n d ~ H o w a r d ~ H u g h e s ~ M e d i c a l ~ I n s t i t u t e, ~ Y a l e ~ U n i v e r s i t y, ~ N e w ~ H a v e n ~ C T . ~}$

of the drug so that in each case the treated ear could be compared with the untreated ear.

Most of the cells in the cochlea are not sensory cells but rather are located within the spiral ligament. Relatively little is known about the functional significance of most of these cells but increasing evidence indicates that their integrity is crucial for normal hearing. There are a number of morphologically distinctive cell types within the ligament, the most abundant of which is the type I fibrocyte. Type I fibrocytes have been found to show marked cytochemical changes that progressed with development of endolymphatic hydrops in the guinea pig hydrops model (Ichimiya et al. 1994a), a finding that strongly suggested that these cells play an essential role in control of cochlear fluid volume. All cells within the ligament are interconnected via gap junctions, one consequence of which is that it makes possible the recycling of potassium ions from the organ of Corti to the stria vascularis (Kikuchi et al. 2000). The importance of the integrity of cochlear gap junctional systems for hearing has recently been emphasized by findings that mutations in genes encoding three different gap junction proteins that are present in the ligament can result in deafness (Kelsell et al. 2001). The size, form, and complexity of the spiral ligament indicate that this structure is far more complex than merely a pathway for potassium ions. Understanding the functions of the spiral ligament and other nonsensory portions of the cochlea will be promoted by learning more about cytochemical profiles of given cell types and about how these profiles can be experimentally altered. In the present report cyto- chemical profiles of type I fibrocytes and other nonsensory cells were confirmed and extended, and some were found to be quite susceptible to disruption following gentamicin treatment. A diverse array of compounds was tested in search for clues regarding the chemical nature and vulnerabilities of various cell types.

Ion transport proteins are obviously important for maintaining ionic balance within and between cochlear fluids. In the present study immunostaining is used to assay for the following transport proteins: $\mathrm{Na}^{+}, \mathrm{K}^{+}$-ATPase, the $\mathrm{Na}^{+}, \mathrm{Ca}^{++}$exchanger, the membrane-bound $\mathrm{Ca}^{++}$-ATPases, plasma membrane calcium-ATPase (PMCA) and smooth endoplasmic reticulum calcium-ATPases SERCA1 and SERCA2, as well as carbonic anhydrase (CA), all of which play major roles in controlling intracellular ion content. A variety of calcium-binding proteins are known to be present in the inner ear where they are thought to play diverse roles, including but not limited to transduction, motile responses, and neurotransmitter release (Rabie et al. 1983; Dechesne et al. 1991; Flock et al. 1986; Slepecky and Ulfendahl 1993; Ichimiya et al. 1994a,b). The following calcium-binding compounds were assayed: peptide 19, calretinin, calbindin, S-100, osteopontin, calmodulin, and caldesmon. In addition, the inositol 1,4,5-triphosphate receptor $\left(\mathrm{IP}_{3} \mathrm{R}\right)$ was assayed. The $\mathrm{IP}_{3} \mathrm{R}$, which has not previously been localized in the ear, is an intracellular $\mathrm{Ca}^{++}$ channel that is gated by inositol 1,4,5-triphosphate $\left(\mathrm{IP}_{3}\right)$ and regulates cytosolic $\mathrm{Ca}^{++}$as a second messenger (Kuno and Gardner 1987; Worley et al. 1987). Calcium-binding proteins and the $\mathrm{IP}_{3} \mathrm{R}$ very likely 
A

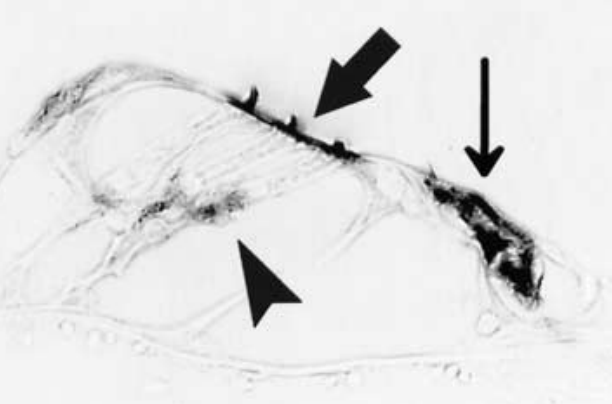

\section{PMCA}

B

C

$C^{\prime}$

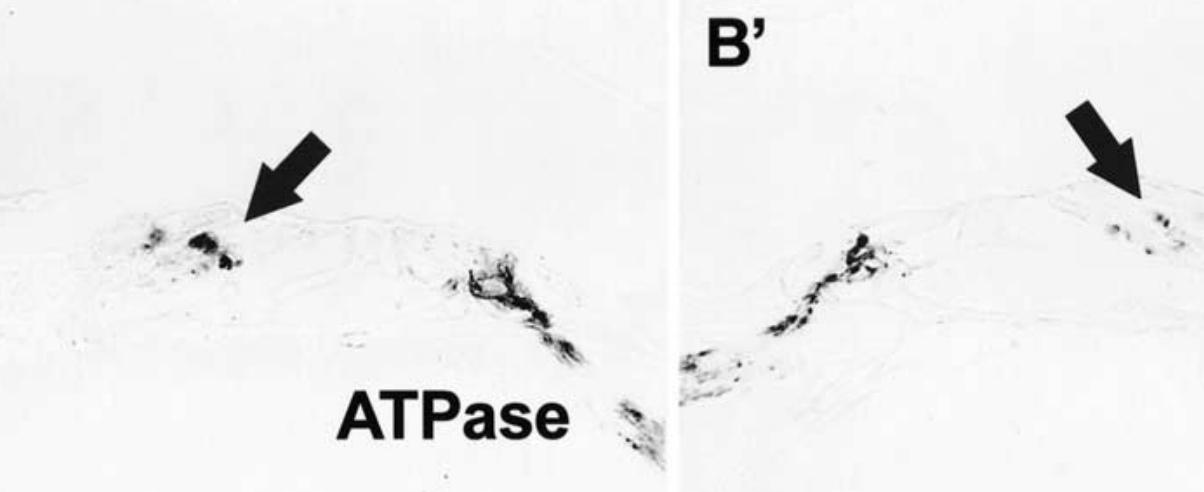

$A^{\prime}$

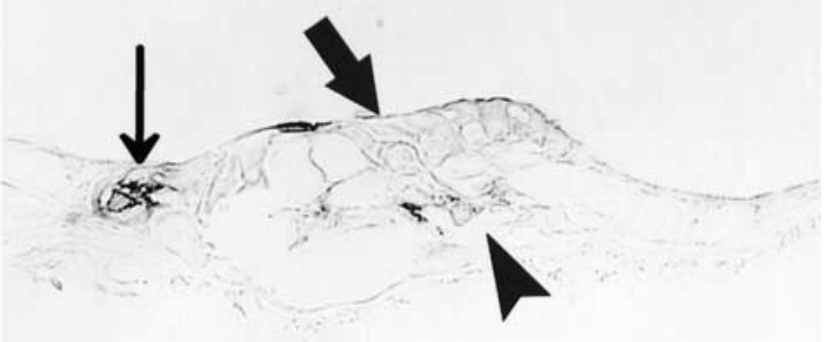

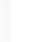

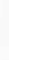

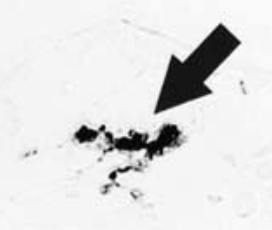

200 kD NF

FIG. 1. Changes of immunostaining in the organ of Corti. In this and all other figures, pairs of images are presented from a given specimen. In each case the image on the left is the untreated control cochlea and that on the right is the gentamicin-treated cochlea. Corresponding portions of the cochleas are shown so that the images appear as mirror images of each other. $\mathbf{A}, \mathbf{A}^{\prime}$. The cytosol of inner hair cells (IHCs) (small vertical arrow) and the stereocilia and cuticular plate of the outer hair cells (OHCs) (large diagonal arrow) on control side $(\mathbf{A})$ are positive for PMCA-ATPase. On the treated side $\left(\mathbf{A}^{\prime}\right)$, immunostaining of $\mathrm{OHCs}$ is missing and IHCs show weaker staining.

play complementary roles in calcium regulation within the inner ear. Further proteins included the brain form of creatine kinase (CKBB), connexin 26, vimentin, and neurofilaments. CKBB facilitates
Arrowheads indicate staining of Deiters' cell cups. B, B'. Nerve terminals beneath $\mathrm{OHCs}$ and IHCs in the control side $(\mathbf{B})$ are positive for $\mathrm{Na}^{+}, \mathrm{K}^{+}$-ATPase. On the treated side $\left(\mathbf{B}^{\prime}\right)$, the staining of terminal of OHCs is decreased (arrow), but that of IHCs is not clearly decreased. $\mathbf{C}, \mathbf{C}^{\prime}$. Nerve fibers beneath $\mathrm{OHCs}$ and IHCs in the control side $(\mathbf{C})$ are positive for $200 \mathrm{kD}$ neurofilaments. On the treated side $\left(\mathbf{C}^{\prime}\right)$, only nerve terminals beneath IHCs are immunopositive. Those beneath $\mathrm{OHCs}$ are not stained. Survival periods: $\mathbf{A}=4$ days, $\mathbf{B}, \mathbf{C}=1$ month. Scale bar in $\mathbf{A}=20 \mu \mathrm{m}$ and applies to all images.

transfer of high-energy phosphate from creatinine phosphate to ADP and may provide ATP to the abovementioned energy-dependent ion transport proteins. Connexin 26 is a major cochlear gap junction protein 
that is essential for cochlear function (Kikuchi et al. 1995). The intermediate filament vimentin has been shown to be involved in response to tissue damage (Oesterle et al. 1990; Berggren et al. 1990; Calvo et al. 1991; Gallanti et al. 1992; SundarRaj et al. 1992; Usami et al. 1993) and has been reported to be present within the cochlea (e.g., Anniko et al. 1987; Schulte and Adams 1989b; Shi et al. 1993). Staining for neurofilaments was used to judge nerve fiber density.

\section{MATERIALS AND METHODS}

\section{Animal treatment}

Twenty-six albino guinea pigs (weighing 250-450 g) with normal Preyer reflexes were used in this study. The animals received a local application of gentamicin according to the following procedure. Under pentobarbital anesthesia $(30 \mathrm{mg} / \mathrm{kg})$, the round window of each right ear was exposed using the retroauricular approach. In 11 animals, a $50 \mu \mathrm{l}$ drop of a commercially prepared gentamicin solution (SoloPak Laboratories Inc. Elk Grove Village. IL; $40 \mathrm{mg} / \mathrm{ml}$ ) was placed on the round window. In 14 animals, gentamicin powder (Sigma Chemical Co., St. Louis, MO) dissolved $(40 \mathrm{mg} / \mathrm{ml})$ in an artificial perilymph solution (glucose $5.5 \mathrm{mM}, \mathrm{NaCl} 120 \mathrm{mM}$, KCl $1.5 \mathrm{mM}$, and HEPES buffer $20 \mathrm{mM}$, pH adjusted to 7.3 with $\mathrm{NaOH}$ ) was applied to the round window membrane. One animal received an application of only the vehicle used in the commercial solution (sodium bisulfite $3.2 \mathrm{mg}$, edetate disodium $0.1 \mathrm{mg}$, methylparaben $1.8 \mathrm{mg}$, and propylparaben $0.2 \mathrm{mg} / \mathrm{ml}, \mathrm{pH}$ adjusted to 4.2 with sodium hydroxide). Survival times of cases reported in the present report ranged from 4 days to 6 months. A complete description of the treatment conditions is given in the accompanying article.

\section{Tissue preparation}

The animals were deeply anesthetized with urethane $(1.5 \mathrm{~g} / \mathrm{kg})$, and were killed by transcardial perfusion with $200 \mathrm{ml}$ warm physiological saline containing $0.1 \%$ sodium nitrite, followed by $200 \mathrm{ml}$ of fixative. Each bulla was opened rapidly, the stapes was removed, the round window was perforated, and the cochlear scalae were perfused with approximately $1 \mathrm{ml}$ of the same fixative. The specimens were fixed for $2 \mathrm{~h}$ at room temperature. The fixative was $10 \%$ formalin in saline containing $0.5 \%$ zinc dichromate with the $\mathrm{pH}$ adjusted to 5.0 with $\mathrm{NaOH}$ just prior to use. The specimens were immersed in 0.12 M EDTA and stirred gently for 3 weeks. The decalcified specimens were dehydrated in ethanol, cleared in xylene, and embedded in paraffin. Serial $6 \mu \mathrm{m}$ sections were cut in the horizontal plane from each paraffin block and mounted on glass slides. Every 20th section was stained with H\&E. Both treated and opposite (nontreated) ears were processed together during all above-mentioned steps.

\section{Immunohistochemical staining procedures}

The sources, dilutions, and characterizations of the antibodies used in this study are listed in Table 1.

Deparaffinized sections were immunostained with the biotin-amplified ABC method (Adams 1992). Each section was exposed to a $5 \%$ solution of normal horse serum (NHS) in $0.1 \mathrm{M}$ phosphate-buffered saline $\mathrm{pH} 7.2$ (PBS) for $1 \mathrm{~h}$ to preabsorb sites of nonspecific antibody binding, and then incubated for $12 \mathrm{~h}$ at room temperature with one of the primary antibodies diluted with $1 \%$ NHS-PBS. Sections were rinsed in PBS and flooded with a 1:200 dilution of biotinylated antimouse IgG or antirabbit IgG (Jackson Immunoresearch Laboratories, West Grove, PA) in 1\% NHS-PBS for $1 \mathrm{~h}$, rinsed in PBS, and incubated with Vectastain $\mathrm{ABC}$ reagent (Vector Laboratories, Burlingame, CA) for $1 \mathrm{~h}$. The sections were rinsed in PBS and incubated in biotinylated tyramine (BT) solution with $0.01 \% \mathrm{H}_{2} \mathrm{O}_{2}$ for $10 \mathrm{~min}$. The BT was made according to the previous report (Adams 1992) and diluted 1:100 with PBS just prior to use.

Sections were then rinsed with PBS and incubated with ABC again for $30 \mathrm{~min}$. Sites of bound primary antibodies were visualized by development in $0.05 \%$ $3,3^{\prime}$-diaminobenzidine- $0.01 \% \quad \mathrm{H}_{2} \mathrm{O}_{2}$ substrate medium in $0.1 \mathrm{M}$ phosphate buffer. Control procedures included omission of primary antisera from the staining sequence and limiting dilutions of primary antisera. Both treated and nontreated ears were immunostained together so that the nontreated ear served as the control for staining with each of the antibodies.

FIG. 2. Changes of immunostaining in hair cells with 7 days survival following local application of gentamicin. A, $\mathbf{A}^{\prime}$. Arrows indicate third row of OHCs. OHCs (arrows) and (IHCs) on the control side (A) are positive for peptide 19 . On the treated side $\left(\mathbf{A}^{\prime}\right)$, only IHCs are stained. Arrow in $\mathbf{A}^{\prime}$ indicates the location of unstained OHCs. B, $\mathbf{B}^{\prime}$. IHCs and $\mathrm{OHCs}$ of the control side (B) are immunoreactive for calbindin. There is decreased staining on the treated side $\left(\mathbf{B}^{\prime}\right)$. $\mathbf{C}, \mathbf{C}^{\prime}$. IHCs and OHCs on the control side $(\mathbf{C})$ are positive for calmodulin. On the treated side $\left(\mathbf{C}^{\prime}\right)$, only IHCs are positive. D, D'. IHCs, Hensen's cells, and Deiters' cells of the control side $(\mathbf{D})$ are positive for calretinin. On the treated side $\left(\mathbf{D}^{\prime}\right)$, staining of Deiters' cells and Hensen's cells is decreased. Scale bar in $\mathbf{A}=20 \mu \mathrm{m}$. 
A

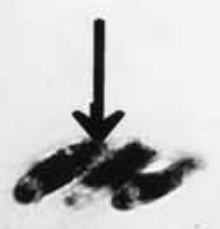

Pep19

\section{B}

CaB

C

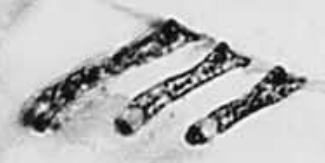

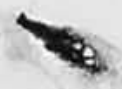

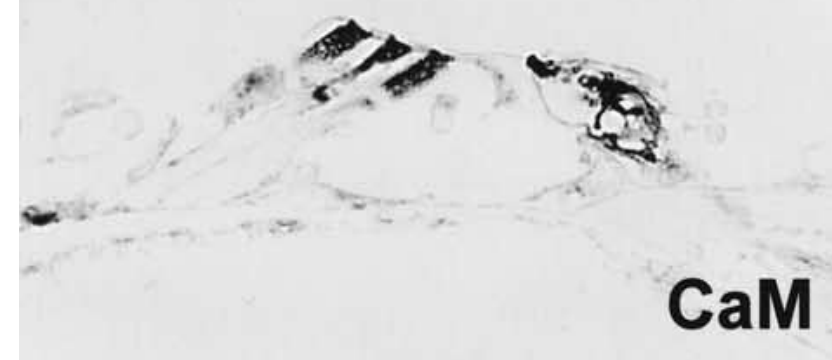

\section{CaM}

D

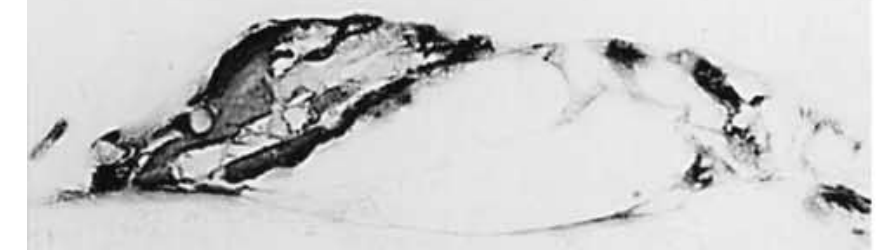

D

$A^{\prime}$

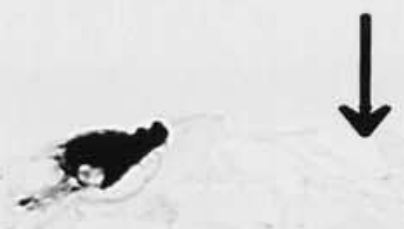

B'

C'
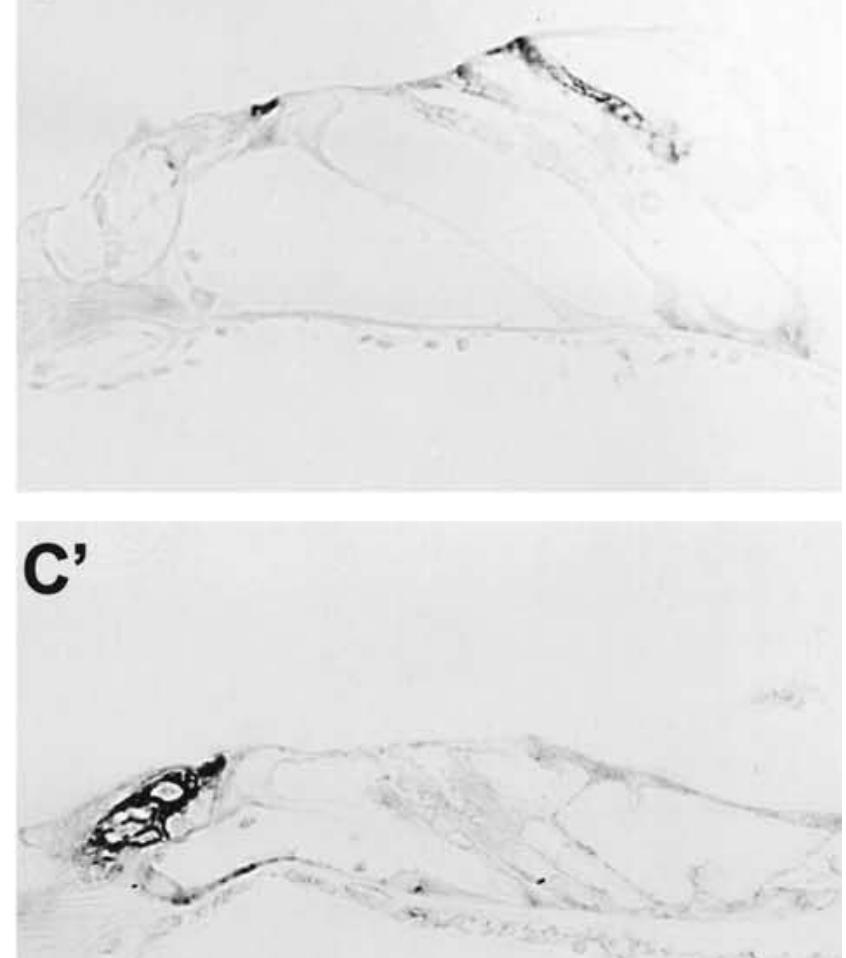

\section{CaR}

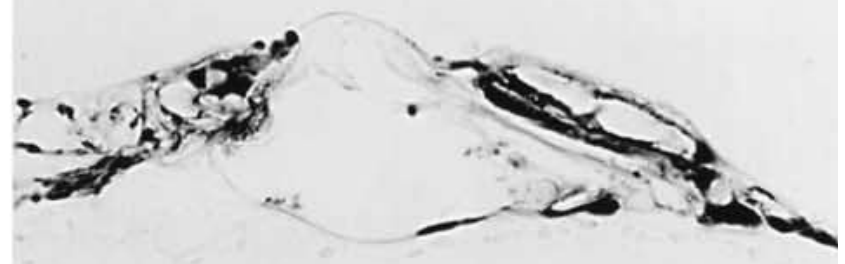




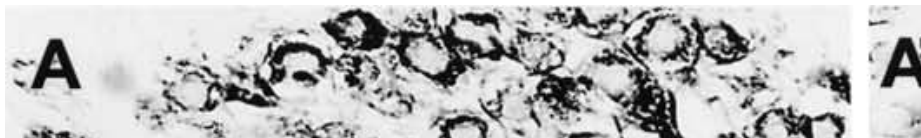

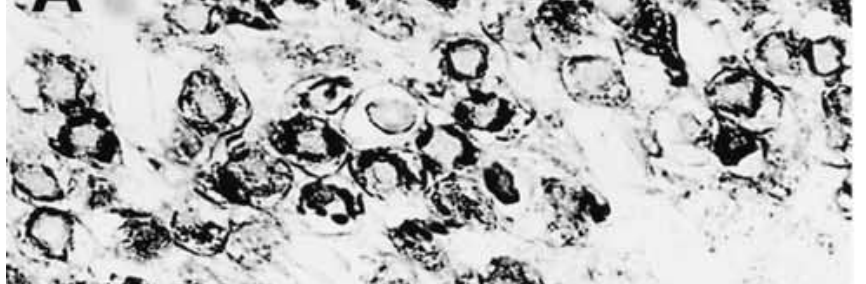
cis $>2+5$

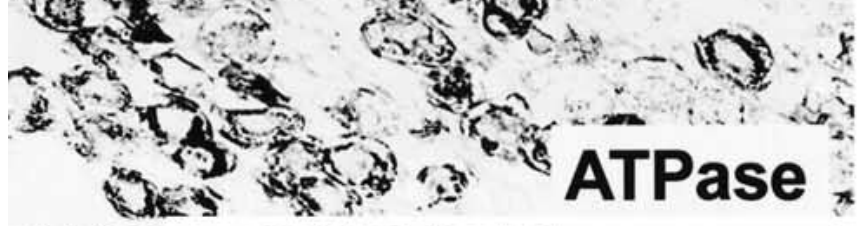
B 30 a

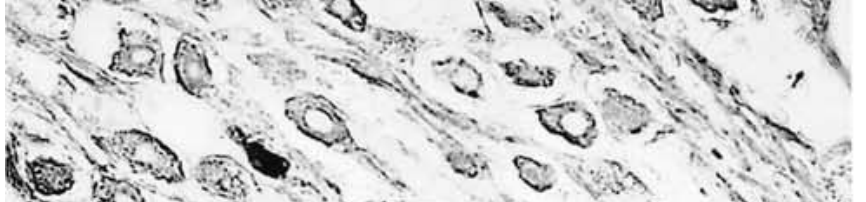
Q $6-10$ 200kD NF

C 40 $72^{2}, 0 \%$

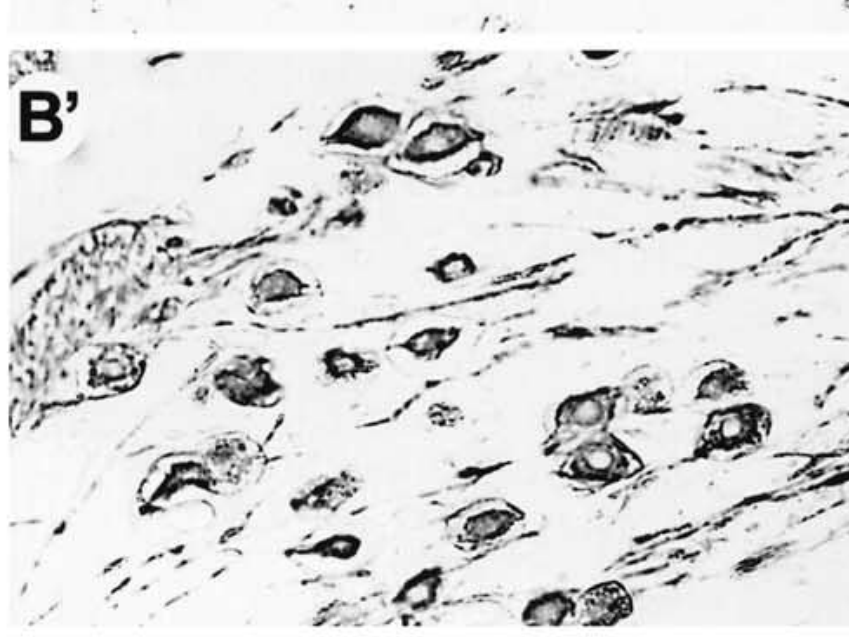

C'

(3)

" W

2

s.

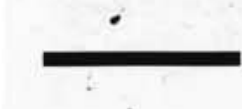

acis

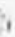

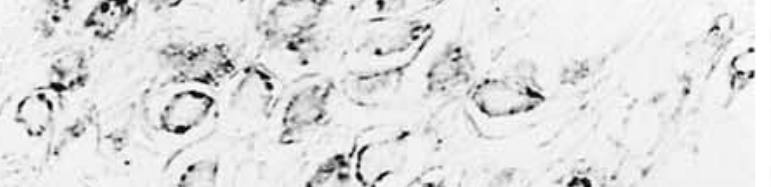
(3) $a^{2}{ }^{3}$

\footnotetext{
D

SERCA 1 - 20
} 


\section{RESULTS}

Changes in cytochemistry of cells that survived the gentamicin treatment varied among antibodies, cell classes, and survival periods. The extent or even the nature of observed changes was not always commensurate with the degree to which individual cell types accumulated gentamicin. Unfortunately, there is insufficient understanding of the organization of the cochlea to provide a conceptual framework upon which to base descriptions of chemical systems in various tissues or of changes in cytochemistry following experimentation. For this reason the results will be described by individual regions within the tissue and according to characteristic staining properties for given cell types. These descriptions are anticipated to contribute toward establishing more adequate conceptual frameworks for future investigations.

\section{Results are summarized in Table 2.}

\section{Organ of corti}

In severely damaged cases, where degeneration of the organ of Corti extended to the upper turns, immunostaining of the organ of Corti for all antibodies was absent in surviving cells. In cases without apical hair cell loss, the following changes were present.

Inner hair cells. In control ears, immunostaining for PMCA was present in inner hair cells (IHCs) (Fig. $1 \mathrm{~A}$, small arrow). In mildly damaged cases, immunostaining for PMCA was reduced (Fig. $1 \mathrm{~A}^{\prime}$, small arrow), but less than in outer hair cells (OHCs) (see below).

In control ears, IHCs were positive for peptide 19 (Fig. 2A), calbindin (Fig. 2B), calmodulin (Fig. 2C), and calretinin (Fig. 2D). In cases with $\mathrm{OHC}$ degeneration that did not include IHC loss, staining for calcium-binding proteins in IHCs was absent. However, in some cases, IHCs were positively immunostained for calcium-binding proteins in sections that showed no staining of otherwise normal-appearing OHCs (Fig. 2A', $\mathrm{C}^{\prime}$ ).

FIG. 3. Changes of immunostaining in the spiral ganglion cells. $\mathbf{A}, \mathbf{A}^{\prime}$. The periphery of spiral ganglion cells in the control ear $(\mathbf{A})$ are positive for $\mathrm{Na}^{+}, \mathrm{K}^{+}$-ATPase. The number of cells and intensity of the immunostaining is decreased on the treated side $\left(\mathbf{A}^{\prime}\right)$. B, $\mathbf{B}^{\prime}$. The cytosol of the spiral ganglion cells and nerve fibers in the control ear (B) are immunostained for $200 \mathrm{kD}$ neurofilaments. On the treated side $\left(\mathbf{B}^{\prime}\right)$, the numbers of stained cells and nerve fibers are less. $\mathbf{C}, \mathbf{C}^{\prime}$. The periphery of spiral ganglion cells in the control side $(\mathbf{C})$ are positive for PMCA. On the treated side $\left(\mathbf{C}^{\prime}\right)$, the number of cells and intensity of staining for PMCA are obviously decreased. D, $\mathbf{D}^{\prime}$. The cytosol of spiral ganglion cells in the control side (D) is positive for SERCA1. There is much reduced staining for SERCA1 in the treated ( $\left.\mathbf{D}^{\prime}\right)$ side. Survival periods: $\mathbf{A}=6$ months, $\mathbf{B}=1$ month, $\mathbf{C}, \mathbf{D}=3$ months. Scale bar in $\mathrm{A}^{\prime}=50 \mu \mathrm{m}$.
Outer hair cells. Immunostaining for PMCA was present in the cuticular plate and stereocilia of OHCs (Fig. 1A, large arrow). In mildly damaged cases, immunostaining of the cuticular plate and stereocilia of OHCs for PMCA was absent (Fig. 1A', large arrow). In control ears, OHCs were immunoreactive for peptide 19 (Fig. 2A, arrow), calbindin (Fig. 2B), and calmodulin (Fig. 2C). OHCs in lower turns were frequently absent in treated ears. In cases of $\mathrm{OHC}$ survival, there was often decreased immunostaining for calcium-binding proteins. These findings fit with the well-established fact that OHCs, which more avidly accumulate gentamicin than do IHCs, are more susceptible to disruption and degeneration following gentamicin uptake (see accompanying article and many others cited therein). When OHCs survive following gentamicin treatment, they show more pronounced changes than IHCs in immunostaining for calcium-binding proteins and for PMCA.

Supporting cells. Immunostaining for PMCA was present in Deiters' cells near the bases of OHCs (Fig. 1A, arrowhead). As with IHCs, this staining was less susceptible than OHC staining to gentamicin-induced disruption because it remained in cases where OHC staining was eliminated (Fig. 1A', arrowhead). In control ears, Deiters' cells, Hensen's cells, and inner pillar cells were positive for calretinin (Fig. 2D). Staining for calretinin remained strong, even in cases where OHCs and other cells were missing (Fig. 2D').

\section{Nerve terminals and spiral ganglion cells}

Nerve terminals beneath IHCs and OHCs were positive for $\mathrm{Na}^{+}, \mathrm{K}^{+}$-ATPase (Fig. 1B, arrow) and 200kD neurofilaments (Fig. 1C, arrow). In long-term survival animals, there were obvious decreases in immunostaining of nerve terminals for $\mathrm{Na}^{+}, \mathrm{K}^{+}$-ATPase (Fig. 1B' , arrow) and for $200 \mathrm{kD}$ neurofilaments (Fig. 1C', arrow) beneath OHCs in severely and moderately damaged ears.

In control ears, the perimeters of the spiral ganglion cells were positive for $\mathrm{Na}^{+}, \mathrm{K}^{+}$-ATPase (Fig. 3A) and PMCA (Fig. 3C). The cytosol of spiral ganglion cells was positive for $200 \mathrm{kD}$ neurofilaments (Fig. 3B), SERCA1 (Fig. 3D), and SERCA2 (not shown). Immunostaining for SERCA2 appeared the same as for SERCA1, but the former staining was weaker. In the animals with 1 month or greater survival times and severe or moderate damage to the organ of Corti, there was a decrease in the number of cells and in the intensity of immunostaining of spiral ganglion cells for $\mathrm{Na}^{+}, \mathrm{K}^{+}$-ATPase (Fig. 3A'), 200kD neurofilaments

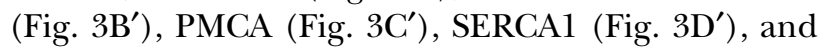
SERCA2 (not shown). Decreased immunostaining for PMCA (Fig. 3C'), SERCA1 (Fig. 3D'), and SERCA2 was more apparent than that of $200 \mathrm{kD}$ neurofilaments (Fig. 3B'). 


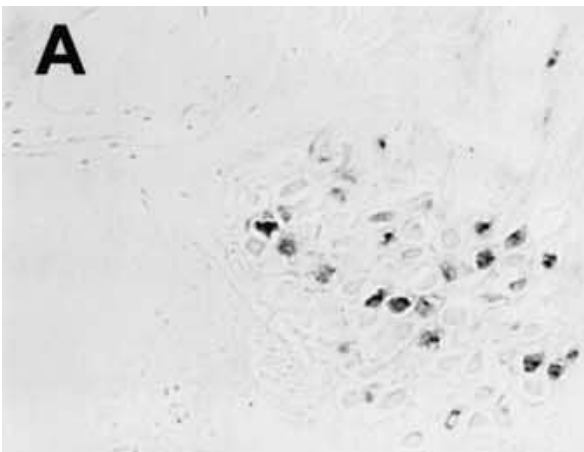

\section{$\mathrm{CaB}$}

\section{B}

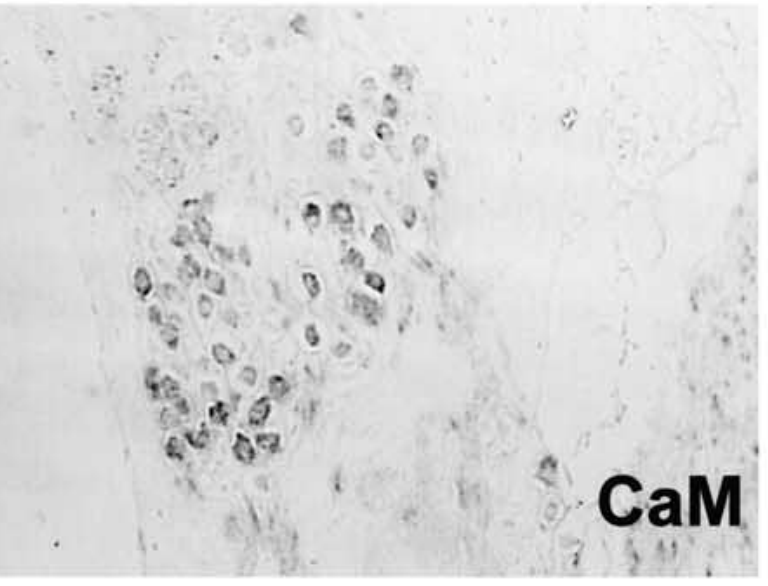

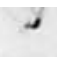

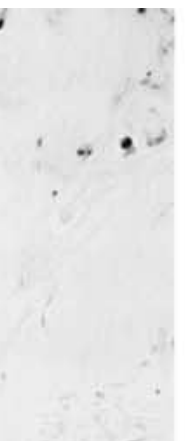

A'

\section{C}
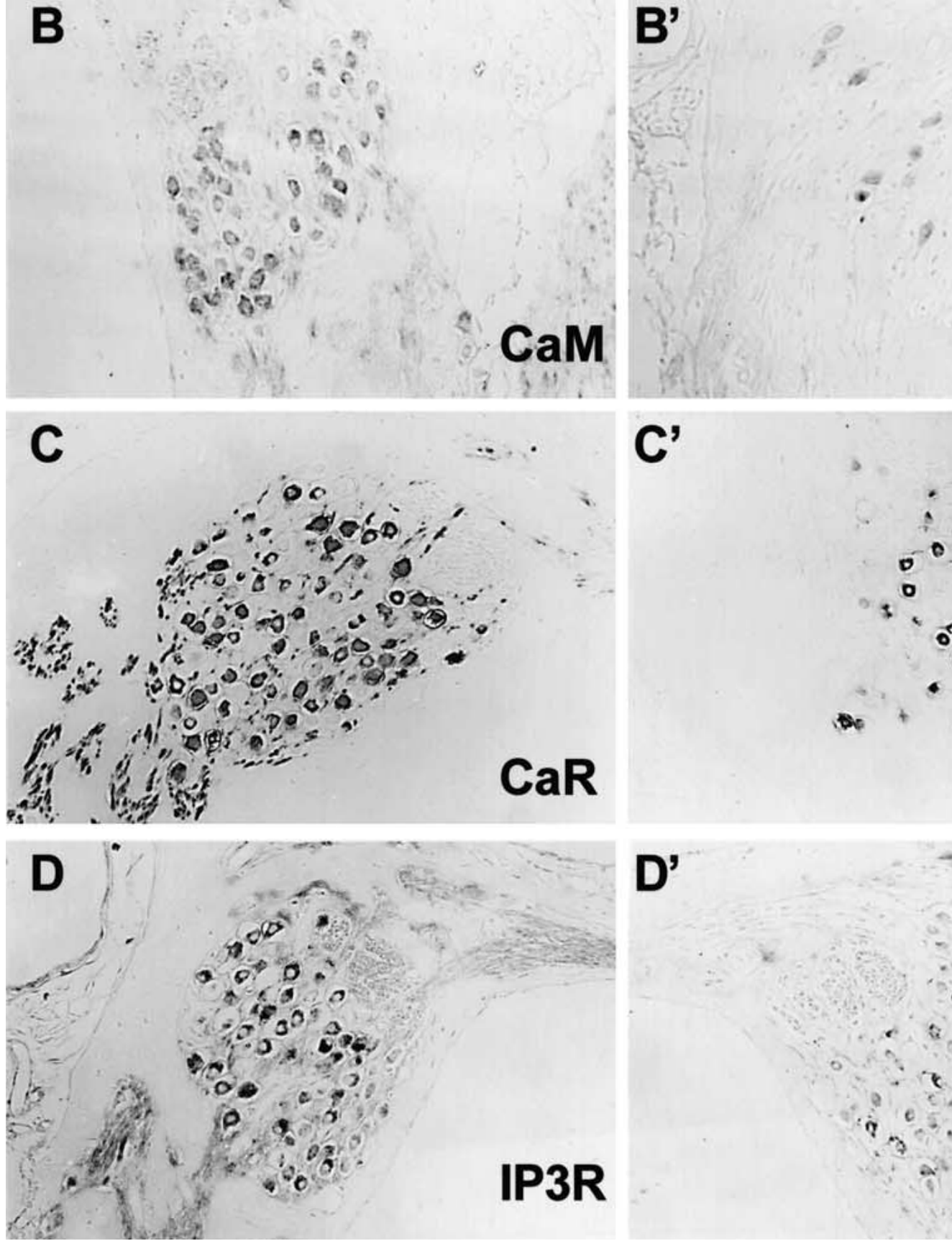

\section{CaM}

$C^{\prime}$

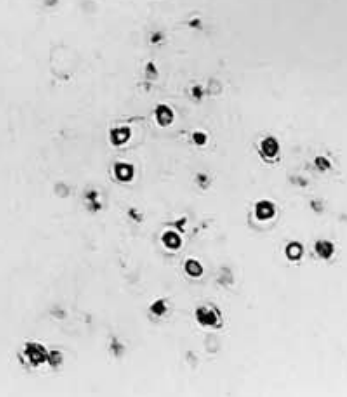

\section{D'}

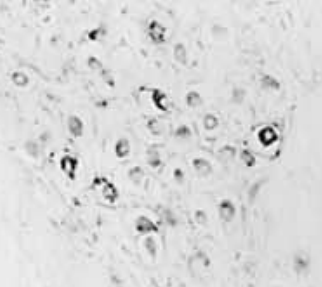


TABLE 2

The degree and range of differences in immunostaining of treated ears in comparison to the untreated controls are indicated by arrows. Mild, moderate, and profound changes are indicated by 1, 2, and 3 arrows

\begin{tabular}{|c|c|c|c|c|c|c|}
\hline Sites & Antigens & $\begin{array}{l}6-24 h \\
(n=3)\end{array}$ & $\begin{array}{c}\text { 4, } 7, \text { days } \\
(n=8)\end{array}$ & $\begin{array}{c}1 \text { month } \\
(n=5)\end{array}$ & $\begin{array}{c}3 \text { months } \\
(n=4)\end{array}$ & 6 months \\
\hline$\overline{\mathrm{IHCs}}$ & PMCA & 0 & $\Downarrow$ & $\Downarrow$ & $\Downarrow$ & $\Downarrow \Downarrow \Downarrow$ \\
\hline $\mathrm{IHCs}$ & Pep19, CaB, CaM, CaR & 0 & $0-\downarrow \Downarrow$ & $\Downarrow \_\Downarrow \Downarrow$ & 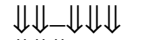 & $\Downarrow \Downarrow$ \\
\hline $\mathrm{OHCs}$ & Pep19, CaB, CaM & 0 & $\downarrow \Downarrow \Downarrow$ & $\downarrow \Downarrow \Downarrow$ & $\Downarrow \Downarrow \Downarrow$ & $\Downarrow \Downarrow \Downarrow$ \\
\hline $\mathrm{OHCs}$ & PMCA & 0 & $\Downarrow \Downarrow$ & $\Downarrow \Downarrow$ & 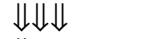 & $\Downarrow \Downarrow \Downarrow$ \\
\hline $\begin{array}{l}\text { Basilar membrane } \\
\text { mesenchymal cells }\end{array}$ & OPN & 0 & $\Downarrow$ & 0 & $\Downarrow$ & 0 \\
\hline Type I fibrocytes & ATPase, PMCA & 0 & 0 & $0-\Downarrow$ & $\Downarrow$ & $\Downarrow$ \\
\hline Type I fibrocytes & OPN, CaM, IP3R & 0 & $0-\Downarrow$ & $0-\Downarrow \Downarrow$ & $\Downarrow \_\Downarrow \Downarrow$ & $0-\Downarrow \Downarrow$ \\
\hline Type I fibrocytes & $\begin{array}{l}\text { Cx26, SERCA2, CKBB, } \\
\text { NaCaX, Vim, CA }\end{array}$ & 0 & $\Downarrow-\downarrow \Downarrow$ & $\Downarrow \_\downarrow \Downarrow$ & $\Downarrow-\Downarrow \downarrow \Downarrow$ & $\Downarrow-\downarrow \downarrow \downarrow$ \\
\hline Type I fibrocytes & $\begin{array}{l}\text { OPN > CaM, IP3R, CaD > } \\
\quad \text { S-100 }\end{array}$ & 0 & $\Downarrow-\Downarrow \downarrow \Downarrow$ & $\Downarrow \Downarrow-\Downarrow \Downarrow \Downarrow$ & $\Downarrow-\Downarrow \downarrow \Downarrow$ & $\Downarrow-\Downarrow \downarrow \Downarrow$ \\
\hline Type II fibrocytes & $\begin{array}{l}\text { Cx26, ATPase, CKBB, } \\
\text { CA, CaM, Ip3R }\end{array}$ & 0 & $\Downarrow$ & $\Downarrow \Downarrow$ & $\Downarrow-\Downarrow \Downarrow \Downarrow$ & $\Downarrow \downarrow-\Downarrow \downarrow \Downarrow$ \\
\hline Type II fibrocytes & Vim & 0 & $\Uparrow$ & $\Uparrow$ & $\Uparrow$ & 0 \\
\hline Type III fibrocytes & Vim, $\mathrm{NaCaX}$ & 0 & 0 & $\Uparrow-\Downarrow$ & $\Uparrow-\Downarrow$ & $0-\Downarrow$ \\
\hline Type III fibrocytes & CaD, OPN & 0 & $0-\Downarrow$ & $\Uparrow-\Downarrow$ & 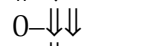 & $0-\Downarrow$ \\
\hline Root cells & CaM, IP3R & 0 & $0-\Downarrow$ & 0 & $0-\Downarrow$ & $0-\Downarrow$ \\
\hline Root cells & SERCA1, SERCA2 & 0 & $0-\Downarrow$ & 0 & $\Downarrow-\downarrow \Downarrow$ & $\Downarrow \Downarrow$ \\
\hline Limbus fibrocytes & Cx26, CKBB, ATPase & 0 & $0-\Downarrow$ & $\Downarrow-\Downarrow \Downarrow$ & $\Downarrow-\Downarrow \Downarrow$ & 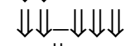 \\
\hline Supralimbal cells & $\mathrm{NaCaX}, \mathrm{Vim}$ & 0 & 0 & $0-\Downarrow$ & $0-\Downarrow$ & $0-\Downarrow$ \\
\hline Interdental cells & SERCA1, SERCA2 & 0 & 0 & & $\Downarrow-\downarrow \Downarrow$ & $\Downarrow \Downarrow \Downarrow$ \\
\hline Nerve terminals & ATPase, NF & 0 & $\Downarrow$ & $\Downarrow \Downarrow$ & $\Downarrow \Downarrow$ & $\Downarrow \Downarrow \Downarrow$ \\
\hline Spiral ganglion & ATPase, NF, SERCA1, SERCA2 & 0 & $0-\Downarrow$ & $\Downarrow-\downarrow \Downarrow \Downarrow$ & $\Downarrow-\Downarrow \Downarrow$ & $\Downarrow \Downarrow$ \\
\hline Spiral ganglion & $\mathrm{CaB}, \mathrm{CaM}, \mathrm{CaR}, \mathrm{IP} 3 \mathrm{R}$ & 0 & $0-\Downarrow$ & $\Downarrow$ & $\Downarrow-\Downarrow \Downarrow$ & $\Downarrow \Downarrow \Downarrow$ \\
\hline
\end{tabular}

Spiral ganglion cells were immunoreactive for calbindin (Fig. 4A), calmodulin (Fig. 4B), calretinin (Fig. 4C), and the $\mathrm{IP}_{3} \mathrm{R}$ (Fig. 4D). In treated ears of animals with 1 month or greater survivals, ganglion cells stained less strongly for these compounds and the number of remaining ganglion cells was de-

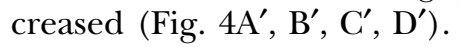

\section{Stria vascularis}

Changes in strial staining for all compounds were generally less pronounced than those in fibrocytes of the spiral ligament or in hair cells. Decreased im-

FIG. 4. Changes of immunostaining in spiral ganglion cells following a local application of gentamicin. $\mathbf{A}, \mathbf{A}^{\prime}$. Some spiral ganglion cells on the control side (A) are positive for calbindin. The number of cells and the intensity of immunostaining are decreased on the treated side $\left(\mathbf{A}^{\prime}\right)$. B, $\mathbf{B}^{\prime}$. Spiral ganglion cells on the control side $(\mathbf{B})$ are positive for calmodulin. The number of cells and the intensity of immunostaining are decreased on the treated side $\left(\mathbf{B}^{\prime}\right)$. C, $\mathbf{C}^{\prime}$. Ganglion cells and nerve fibers of the control side $(\mathbf{C})$ are positive for calretinin. The number of cells and fibers and the intensity of immunostaining are decreased on the treated side $\left(\mathbf{C}^{\prime}\right)$. D, $\mathbf{D}^{\prime}$. Spiral gangilion cells are positive for $I P_{3} R$. The number of cells and the intensity of immunostaining are decreased on the treated side $\left(\mathbf{D}^{\prime}\right)$. Survival periods: $\mathbf{B}=1$ month, $\mathbf{C}, \mathbf{D}=3$ months, $\mathbf{A}=6$ months. Scale bar in $\mathbf{A}=100 \mu \mathrm{m}$. munostaining of the stria vascularis was apparent only in animals with severe damage to the organ of Corti and other tissue. The stria vascularis was immunoreactive for $\mathrm{Na}^{+}, \mathrm{K}^{+}$-ATPase (Fig. 5A) and PMCA (Fig. $6 \mathrm{~A})$. Immunostaining of the stria vascularis for these compounds was decreased in animals with 1 month

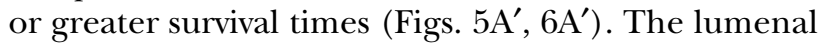
surface of the stria vascularis was immunoreactive for calmodulin (Fig. 7A), osteopontin (Fig. 7B), and $\mathrm{IP}_{3} \mathrm{R}$ (Fig. 6D). In severely damaged ears, there appeared to be a slight decrease in immunostaining of stria vascularis for these proteins (not illustrated). In less severely damaged ears, changes of immunostaining for calmodulin (Fig. $7 \mathrm{~A}^{\prime}$ ), osteopontin (Fig. $7 \mathrm{C}^{\prime}$ ), and $\mathrm{IP}_{3} \mathrm{R}$ (Fig. $6 \mathrm{D}^{\prime}$ ) of the stria vascularis were minor compared with those of the organ of Corti, the spiral ligament, and the spiral limbus. This was true even in the animals with long survival periods.

\section{Spiral ligament}

Type I fibrocytes (see asterisks) of the normal spiral ligament were immunostained for $\mathrm{Na}^{+}, \mathrm{Ca}^{++}$exchanger (Fig. 5B'), carbonic anhydrase (Fig. 5C'), CKBB (Fig. 5D), connexin 26 (Fig. 5E), vimentin (Fig. 5F) and SERCA2 (Fig. 6C). In addition, type I 

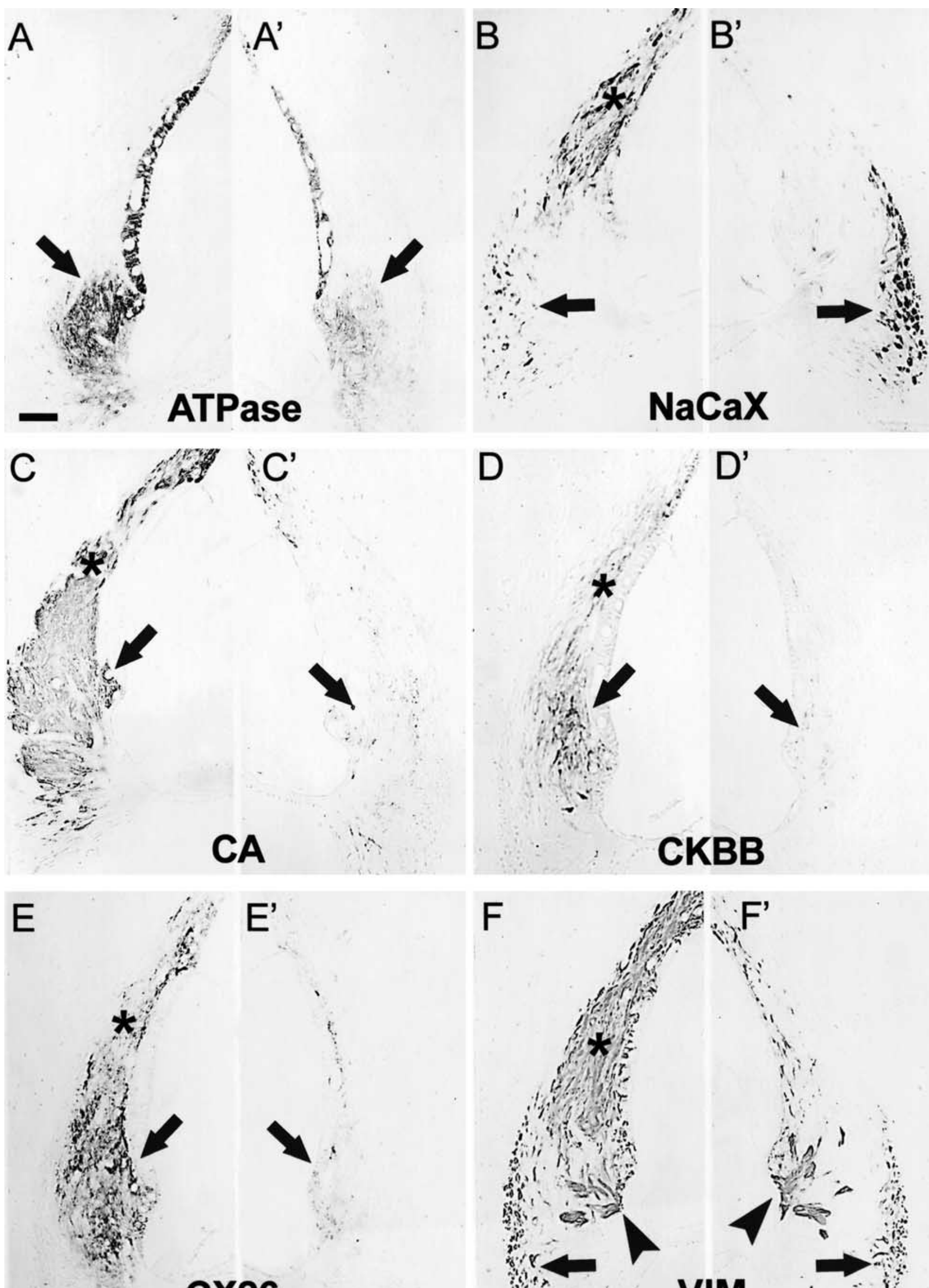

CX26

D

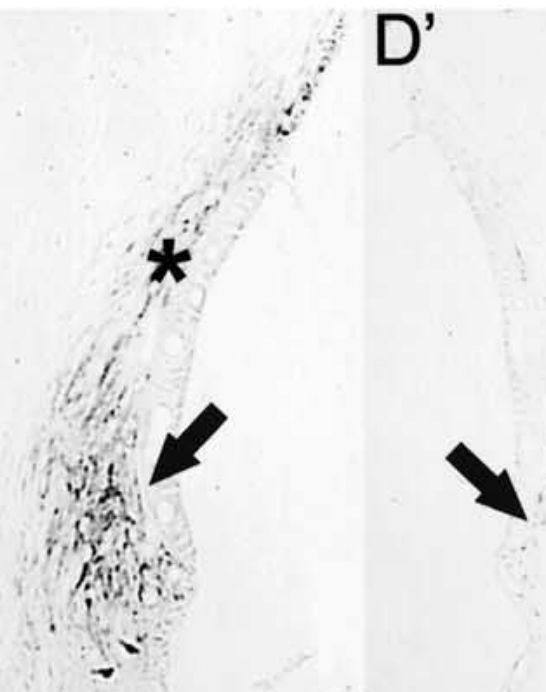

CKBB

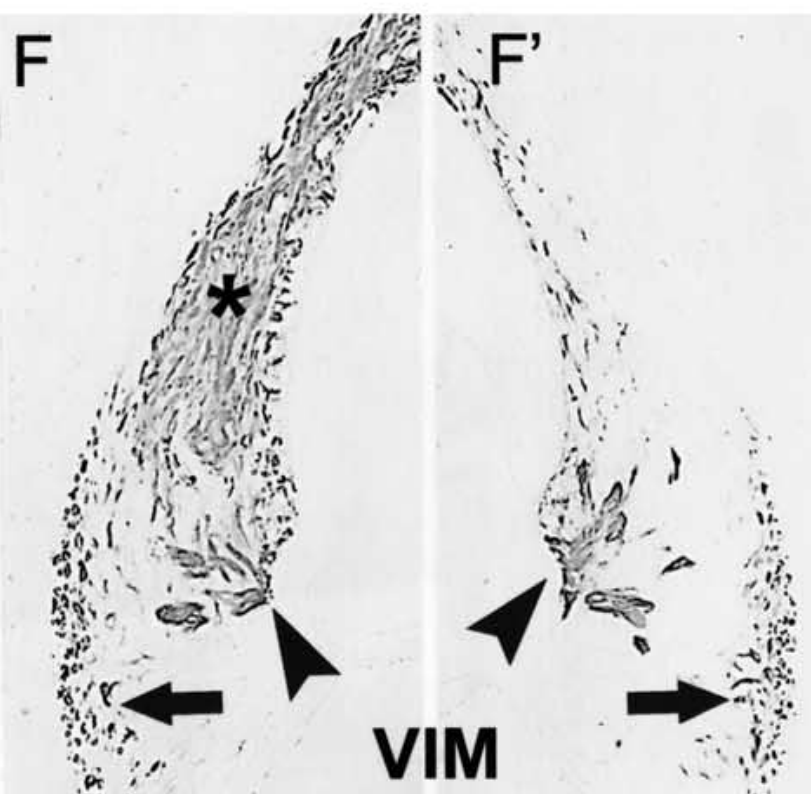


fibrocytes of the spiral ligament were also positive for calmodulin (Fig. 7A), S-100 (Fig. 7C), osteopontin (Fig. 7B), caldesmon (Fig. 7D), and the $\mathrm{IP}_{3} \mathrm{R}$ (Fig. $6 \mathrm{D})$. Decreased immunostaining for all these compounds was apparent beginning at 4-7 day survival times and was quite pronounced in the animals with 3 and 6 month survival periods (see right columns). Decreased immunostaining for connexin 26 (Fig. 5E') and CKBB (Fig. 5D') was more complete than decrements seen with the other above-mentioned antibodies. In cases where there were any surviving type I fibrocytes, immunostaining for the $\mathrm{IP}_{3} \mathrm{R}$ was never completely eliminated (Fig. 6D').

Type II fibrocytes (indicated by arrows) of the spiral ligament were positive for $\mathrm{Na}^{+}, \mathrm{K}^{+}$-ATPase (Fig. 5A), CA (Fig. 5C), CKBB (Fig. 5D), and connexin 26 (Fig. 5E). Decreased immunostaining of type II fibrocytes with these antisera was apparent in the ani-

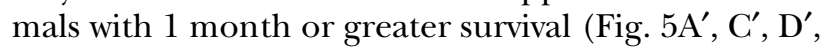
$\mathrm{E}^{\prime}$, arrows). Decreased immunostaining for connexin 26 was more pronounced than that of other antibodies (Fig. 5E'). Immunostaining of type II fibrocytes for vimentin was increased in some cases that showed decreased staining of type I fibrocytes (not shown). Type II fibrocytes were also positive for calmodulin (Fig. 7A) and the $\mathrm{IP}_{3} \mathrm{R}$ (Fig. 6D). This

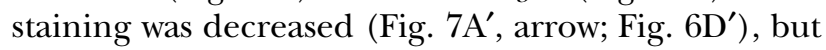
only in the animals with 1 month and longer survival periods.

Type III fibrocytes of the spiral ligament were positive for the $\mathrm{Na}^{+}, \mathrm{Ca}^{++}$exchanger (Fig. 5B, arrow) and for vimentin (Fig. 5F, arrow). In most animals with 7 days or greater survival, immunostaining of type III fibrocytes for these antibodies showed no decrease or a very slight decrease compared with

FIG. 5. Changes of immunostaining in the lateral wall of the cochlea (basal turn) with 1 month survival (1). $\mathbf{A}, \mathbf{A}^{\prime}$. The stria vascularis and type II fibrocytes (arrow) in the spiral ligament of the control side $(\mathbf{A})$ are immunoreactive for $\mathrm{Na}^{+}, \mathrm{K}^{+}$-ATPase. The staining is decreased on the treated side $\left(\mathbf{A}^{\prime}\right)$. B, $\mathbf{B}^{\prime}$. Type I (asterisks) and III fibrocytes (arrows) in the spiral ligament on the control side (B) are immunoreactive for the $\mathrm{Na}^{+}, \mathrm{Ca}^{++}$exchanger. On the treated side $\left(\mathbf{B}^{\prime}\right)$, staining of type I fibrocytes is decreased. In contrast, staining of type III fibrocytes is increased. C, $\mathbf{C}^{\prime}$. Types I (asterisk) and II (arrows) fibrocytes of the spiral ligament in the control side $(\mathbf{C})$ are positive for carbonic anhydrase. There was decreased immunostaining of the types I and II fibrocytes for carbonic anhydrase on the treated side $\left(\mathbf{C}^{\prime}\right)$. D, $\mathbf{D}^{\prime}$. Types I and II fibrocytes of the spiral ligament in the control side are positive for creatinine kinase BB. In the treated ear $\left(\mathbf{D}^{\prime}\right)$, this staining is clearly decreased. E, $\mathbf{E}^{\prime}$. Types I and II fibrocytes of spiral ligament in the control ear (E) are positive for connexin 26. There is decreased immunostaining in the treated side $\left(\mathbf{E}^{\prime}\right) . \mathbf{F}, \mathbf{F}^{\prime}$. Types I (asterisk) and III (arrows) fibrocytes and root cells of the spiral ligament (arrowheads) and basal cells in the stria vascularis in the control side $(\mathbf{F})$ are positive for vimentin. In the treated ear $\left(\mathbf{F}^{\prime}\right)$, immunostaining of type I fibrocytes and basal cells are obviously decreased, but immunostaining of root cells and type III fibrocytes still remains. Scale bar in $\mathbf{A}=50 \mu \mathrm{m}$. other types of fibrocytes (e.g., Fig. 5F'). In some animals, there was an increase in the immunostaining of type III fibrocytes for $\mathrm{Na}^{+}, \mathrm{Ca}^{++}$exchanger (Fig. 5B', arrow) and for vimentin (not illustrated). This increased staining of type III fibrocytes contrasted with decreased immunostaining of type I fibrocytes for the same antigen in the same sections (compare region of the asterisk in $5 \mathrm{~B}$ with that in $5 \mathrm{~B}^{\prime}$ ).

Type III fibrocytes of the spiral ligament were also positive for osteopontin (Fig. 7B, arrow) and caldesmon (Fig. 7D, arrow). This staining was present predominantly in the basal turn. Disparate results were found in changes in immunostaining of type III fibrocytes. In cases that showed severe degeneration of the cochlea, there were slight decreases in staining of these cells for osteopontin and caldesmon. Animals with milder damage showed either no changes or very slight decreases in staining for osteopontin and caldesmon. In half of the animals with 7 days or 1 month survival $(n=5)$, there was increased immunostaining of type III fibrocytes for osteopontin (Fig. 7B', arrow), and caldesmon (Fig. 7D', arrow). As with the $\mathrm{Na}^{+}$, $\mathrm{Ca}^{++}$exchanger above, within the same sections immunostaining of type I fibrocytes for osteopontin and caldesmon was decreased in those instances (compare regions of the asterisks in Figs. $7 \mathrm{~B}$ and $7 \mathrm{D}$ with the same regions in $7 \mathrm{~B}^{\prime}$ and $7 \mathrm{D}^{\prime}$ ).

Root cells of the spiral ligament were intensely positive for vimentin (Fig. 5F, arrowhead), SERCA1 (Fig. 6B, arrow), the $\mathrm{IP}_{3} \mathrm{R}$ (Fig. 6D, arrow) and slightly positive for SERCA2 (Fig. 6C, arrow) and calmodulin (Fig. 7A, open arrow). In most animals with 7 days or greater survival, there were decreases in immunostaining of the root cells (Figs. $5 \mathrm{~F}^{\prime}, 6 \mathrm{~B}^{\prime}, \mathrm{C}^{\prime}, \mathrm{D}^{\prime}, 7 \mathrm{~A}^{\prime}$ ), but the changes were less pronounced than those present in type I and type II fibrocytes.

\section{Spiral limbus}

Fibrocytes in the spiral limbus were positive for $\mathrm{Na}^{+}$, $\mathrm{K}^{+}$-ATPase (Fig. 8A, open arrow), CKBB (Fig. 8C, open arrow), and connexin 26 (Fig. 8D, open arrow). Supralimbal cells were positive for the $\mathrm{Na}^{+}, \mathrm{Ca}^{++}$exchanger (Fig. 8B, arrow) and for vimentin (Fig. 9C, arrow) and less positive for SERCA1 (Fig. 9A, arrow) and for SERCA2 (Fig. 9B, arrow). Decreased immunostaining for $\mathrm{Na}^{+}, \mathrm{K}^{+}$-ATPase (Fig. 8A', open arrow), CKBB (Fig.

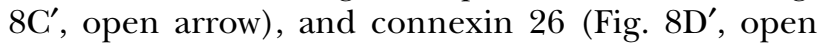
arrow) was commonly present in cases that showed no apparent loss of these cells. In most animals, immunostaining for all these compounds was decreased in both limbal fibrocytes and supralimbal cells (compare respective panels). These changes were restricted to the basal turn. All interdental cells in the spiral limbus were positive for SERCA2 (Fig. 9B, arrowhead), whereas only interdental cells located closer to the 


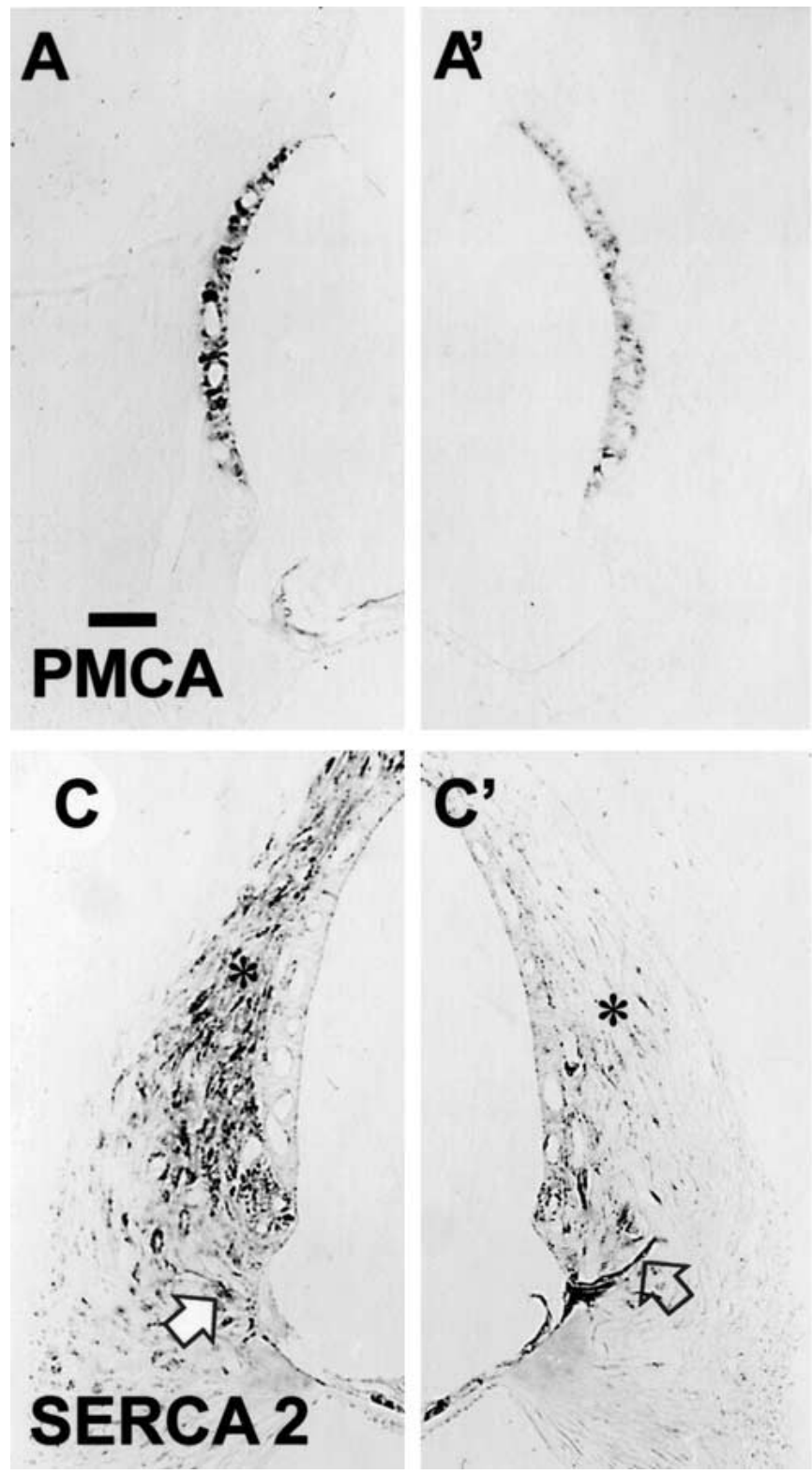

FIG. 6. Changes of immunostaining in the lateral wall of the cochlea (basal turn) with 1 month survival. $\mathbf{A}, \mathbf{A}^{\prime}$. Marginal cells of stria vascularis in the control side $(\mathbf{A})$ are positive for PMCA. There was decreased immunostaining in treated side $\left(\mathbf{A}^{\prime}\right)$. B,, $\mathbf{B}^{\prime}$. Root cells (arrow) in the control ear (B) are positive for SERCA1. In the treated ear $\left(\mathbf{B}^{\prime}\right)$, immunostaining of root cells is slightly decreased. $\mathbf{C}, \mathbf{C}^{\prime}$.

organ of Corti were positive SERCA1 (Fig. 9A, arrowhead). Decreased immunostaining of interdental cells for SERCA1 (Fig. 9A', arrowhead) and SERCA2 (Fig. $9 \mathrm{~B}^{\prime}$, arrowhead) was present in the animals having severe or moderate damage at 1 or more months survival times. These changes were less pronounced than those seen in fibrocytes of the spiral limbus.

Limbal fibrocytes were also positive for the calcium-binding proteins calmodulin (Fig. 10A, open arrow), osteopontin (Fig. 10B), S-100 (Fig. 10C, open arrow), and $\mathrm{IP}_{3} \mathrm{R}$ (Fig. 9D). Supralimbal cells were
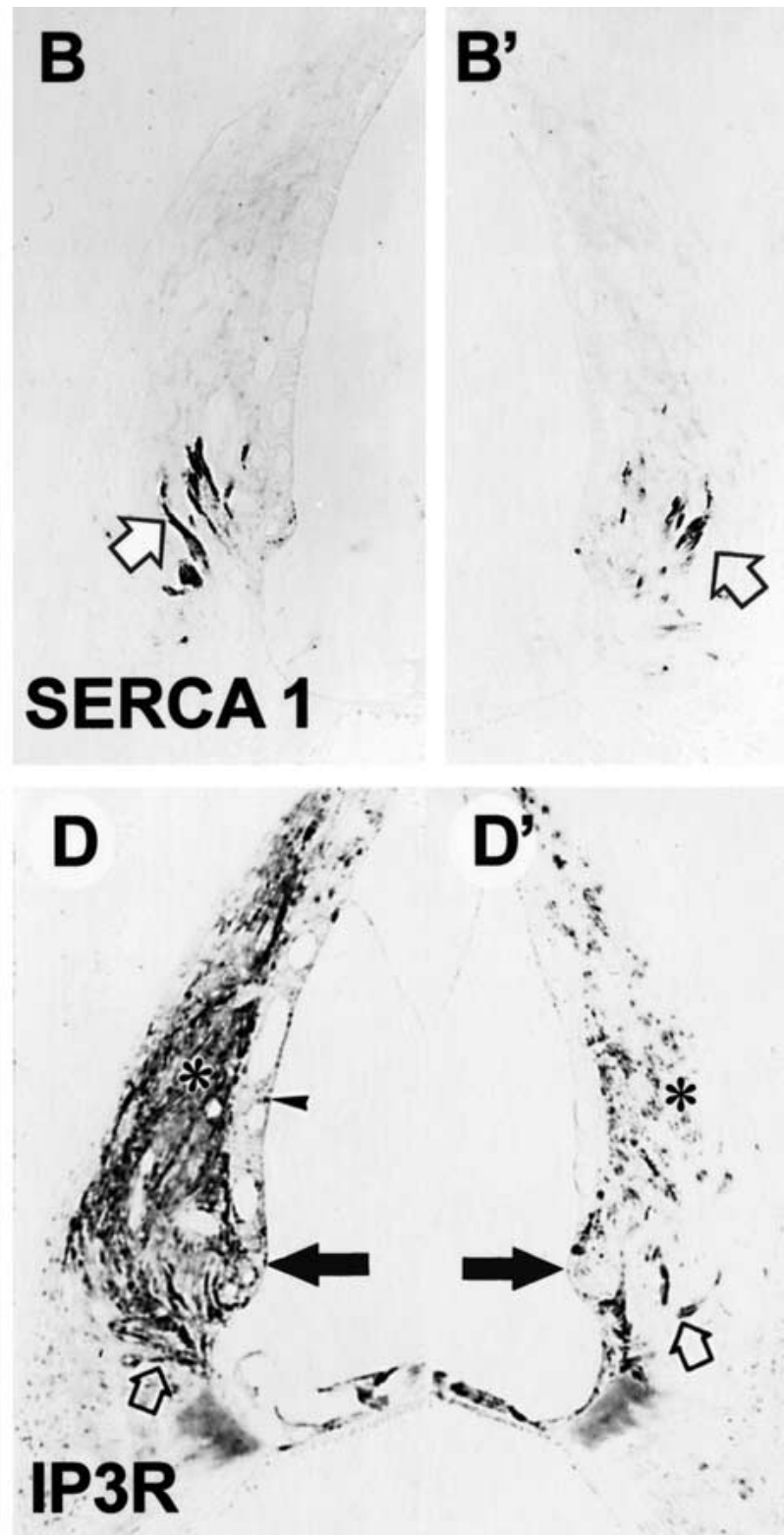

Type I fibrocytes of the spiral ligament in the control ear $(\mathbf{C})$ are positive for SERCA2, and root cells (arrow) are slightly positive. In the treated ear $\left(\mathbf{C}^{\prime}\right)$, there is decreased immunostaining of type I fibrocytes but there is no apparent decease in immunostaining of root cells. The survival period: $\mathbf{A}=7$ days, $\mathbf{B}=6$ months, $\mathbf{C}=3$ months. Scale bar in $\mathbf{A}=50 \mu \mathrm{m}$.

positive for calmodulin (Fig. 10A, closed arrow) and caldesmon (Fig. 10D, arrow). Interdental cells in the spiral limbus were positive for calmodulin (Fig. 10A, arrowhead), osteopontin (Fig. 10B, arrowhead), and $\mathrm{IP}_{3} \mathrm{R}$ (Fig. 9D, arrowhead). In treated animals there was decreased immunostaining for calmodulin, osteopontin, and $\mathrm{IP}_{3} \mathrm{R}$ in both fibrocytes and interdental cells in the limbus (Figs. 10A', B', 9D'). The extent of these decreases was more obvious in fibrocytes than in interdental cells. Decreased immunostaining of the spiral limbus for calmodulin was dramatic (Fig. 

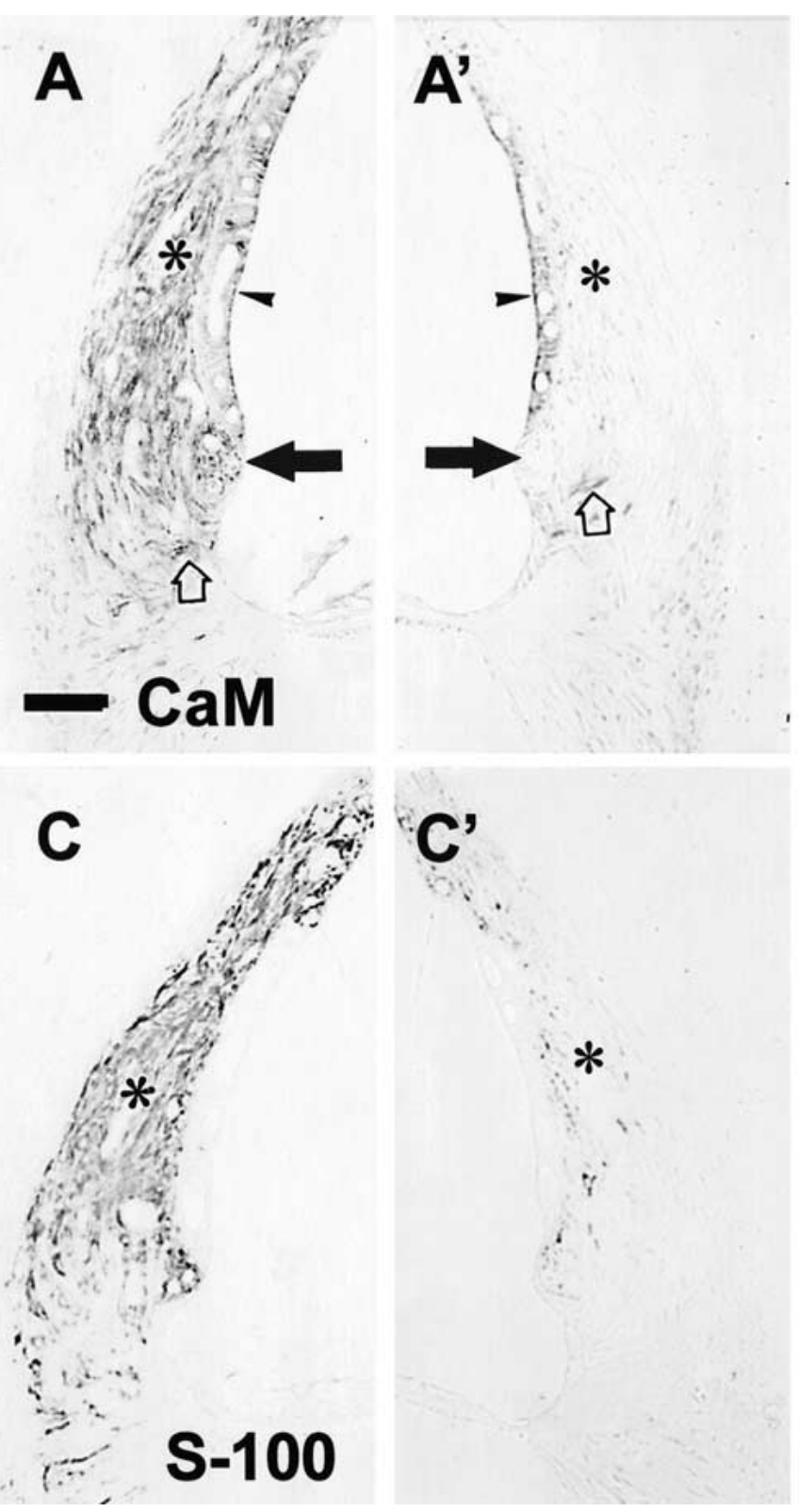

FIG. 7. Changes of immunostaining in the lateral wall of the cochlea (basal turn) with 1 month survival following a local application of gentamicin. $\mathbf{A}, \mathbf{A}^{\prime}$. The lumenal surface of the stria vascularis (arrowhead) and types I (asterisk) and II fibrocytes (arrow) and root cells (open arrow) in the spiral ligament of the control side (A) are positive for calmodulin. Staining of type I and type II fibrocytes is obviously decreased on the treated side $\left(\mathbf{A}^{\prime}\right)$. $\mathbf{B}, \mathbf{B}^{\prime}$. The stria vascularis (arrowhead), types I (asterisk) and III fibrocytes (filled arrow) in the spiral ligament, and mesenchymal cells beneath the

$\left.10 \mathrm{~A}^{\prime}\right)$. In contrast, decreased immunostaining of the same region for $\mathrm{IP}_{3} \mathrm{R}$ was modest (Fig. 9D').

\section{DISCUSSION}

\section{Scope of gentamicin effects}

When critical cells, such as hair cells, are destroyed by aminoglycosides or other insults, it is obvious that the

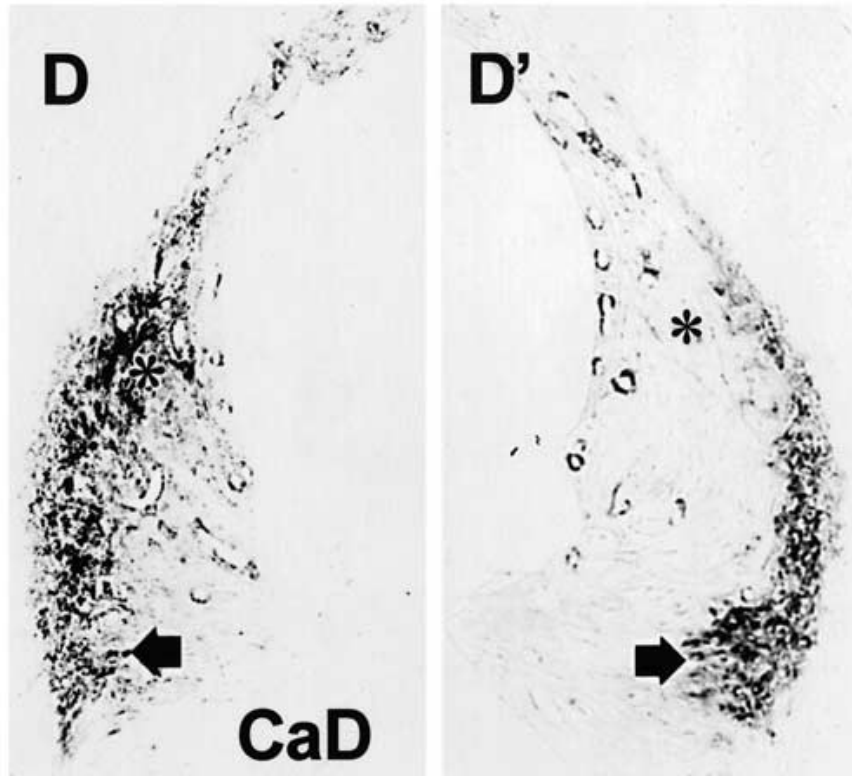

basilar membrane (small vertical arrow) of the control side (B) are immunoreactive for osteopontin. On the treated side $\left(\mathbf{B}^{\prime}\right)$, there is decreased staining of type I fibrocytes. In contrast, there is increased immunostaining of type III fibrocytes. C, $\mathbf{C}^{\prime}$. Type I fibrocytes (asterisk) in the spiral ligament are positive for S-100 protein. Staining is decreased on the treated side $\left(\mathbf{C}^{\prime}\right)$. D, $\mathbf{D}^{\prime}$. Types I (asterisk) and III flbrocytes (arrow) in the spiral ligament are immunoreactive for caldesmon. Staining of type I fibrocytes is decreased on the treated side $\left(\mathbf{D}^{\prime}\right)$. Scale bar in $\mathbf{A}=50 \mu \mathrm{m}$.

cochlea can no longer function properly. When there is apparently only partial trauma and parts of the cochlea retain normal-appearing cells, it is commonly assumed that those cells retain their normal functions. Results of eighth nerve fiber recordings in animals that were chronically treated with aminoglycosides have shown that at least some remaining nerve fibers can be activated by sound but 


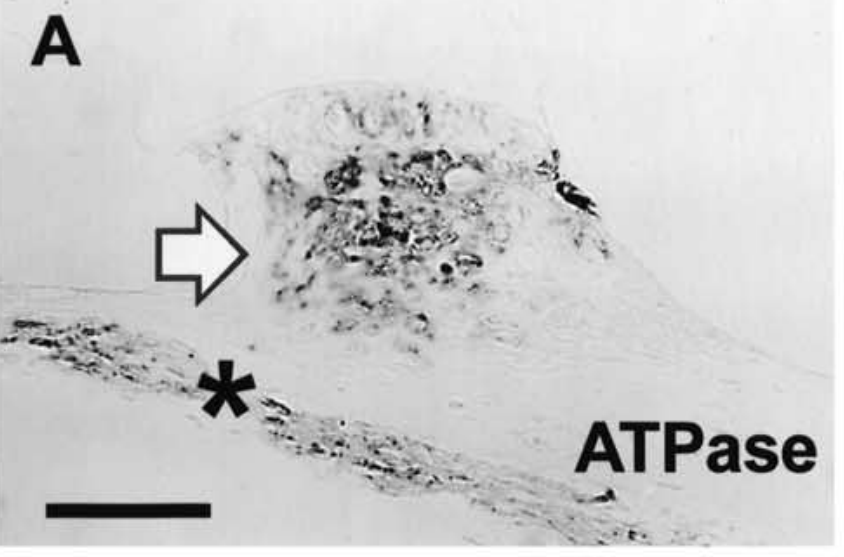

$A^{\prime}$

\section{B}

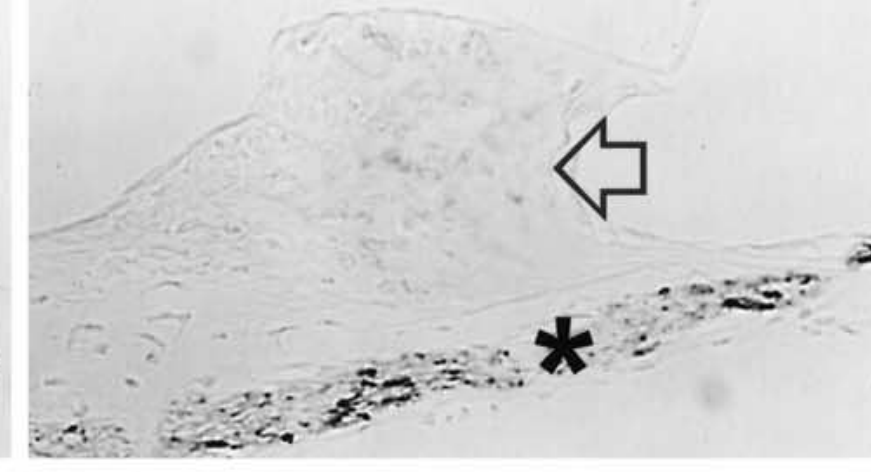

\section{B'}

C

\section{C'}
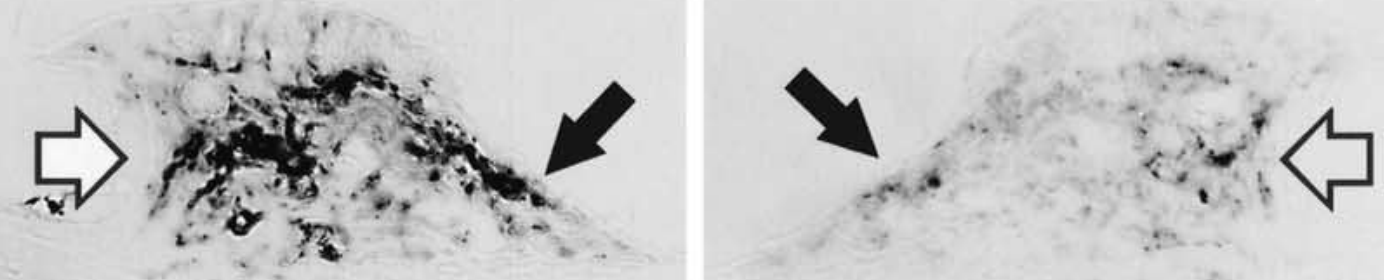

\section{CKBB}

D

D'
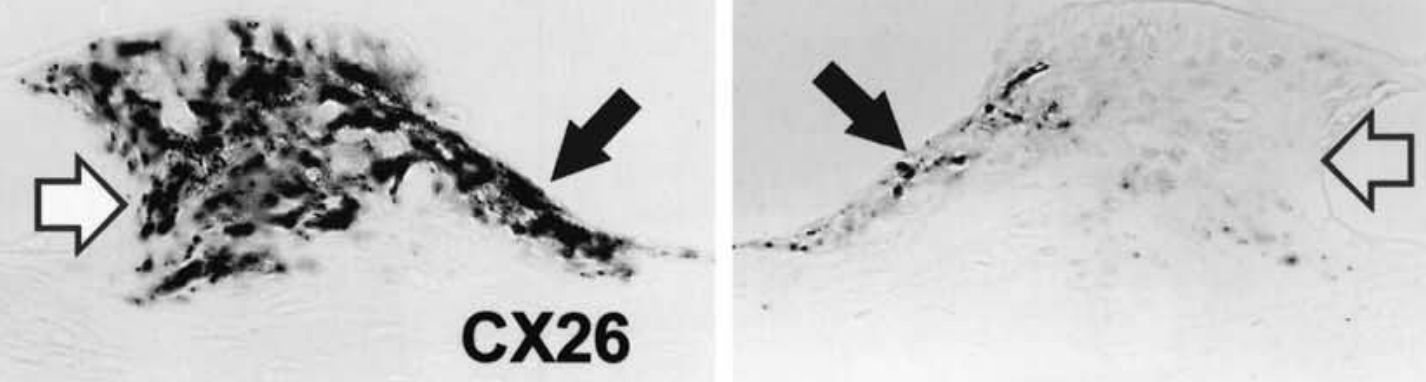
their functional properties are far from normal. (Kiang et al. 1976; Dallos and Harris 1978; Schmiedt et al. 1980; Santi et al. 1982). The present results indicate that following a single local application of gentamicin, parts or even much of the cochlea can retain a normal appearance but the cytochemistry of the surviving cells can be changed to such a degree that normal function should not be assumed to be retained. Surviving hair cells, neurons, and most cells in the spiral ligament and limbus showed pronounced cytochemical changes following gentamicin exposure, even in those cases where the cells' appearance was normal as judged by routine light microscopy.

It is not clear which of the effects reported herein may contribute to the unusual activity of nerve fibers in aminoglycoside-treated ears. However, there are many possible ways in which changes reported herein could contribute to pathological nerve fiber activity. For example, based upon what is known about loss of hearing due to genetic defects in the connexin 26 gene (e.g., Cohn and Kelley 1999), one could expect that the presently reported changes in immunostaining for connexin 26 alone would be associated with profound hearing losses. The combined effects of all the cytochemical changes indicated in Table 2 surely reflect compromised function in the surviving tissue. Therefore, the present results indicate that local administration of gentamicin can induce widespread dysfunction of many cochlear cells in addition to the well-known toxic effects upon sensory cells. The scope of inner ear pathology that is induced by gentamicin is clearly much greater than has previously been recognized.

\section{Susceptibility to damage}

The widespread cytochemical effects of gentamicin were not always predictable from the extent to which given cell classes accumulated the drug. It is well known that hair cells are quite vulnerable to gen-

FIG. 8. Changes in immunostaining of the spiral limbus with 1 month survival. $\mathbf{A}, \mathbf{A}^{\prime}$. fibrocytes (arrow) in the spiral limbus and nerve fibers (asterisk) of the control side (A) are positive for $\mathrm{Na}^{+}, \mathrm{K}^{+}$ATPase. Staining of fibrocytes is decreased in the treated side $\left(\mathbf{A}^{\prime}\right)$. Cells in the supralimbal area (arrow) of the control side (B) are positive for the $\mathrm{Na}^{+}, \mathrm{Ca}^{++}$exchanger. Immunostaining on the treated side $\left(\mathbf{B}^{\prime}\right)$ is decreased. Fibrocytes (open arrow) and supralimbal cells (closed arrow) in the spiral limbus of the control side $(\mathbf{C})$ are positive for creatine kinase isozyme BB. Staining for both cell types on the treated side $\left(\mathbf{C}^{\prime}\right)$ is decreased. Fibrocytes (open arrow) and supralimbal cells (closed arrow) in the spiral limbus of the control side (D) are positive for connexin 26. There is decreased immunostaining of both cell types on the treated side $\left(\mathbf{D}^{\prime}\right)$. Scale bar in $\mathbf{A}=50 \mu \mathrm{m}$. tamicin toxicity and it is usually assumed that the toxic effects are direct. In the accompanying article, it was found that OHCs accumulated gentamicin more avidly than IHCs. In the present article, OHCs showed decreased staining for constituents earlier and to a greater extent than did IHCs. These results indicate that cytochemical effects of gentamicin administration in hair cells are commensurate with their proclivity for gentamicin accumulation. On the other hand, type I fibrocytes never showed granular cytoplasmic staining for gentamicin as did hair cells, but they showed cytochemical changes following gentamicin treatment that occurred as early and were at least as profound as the changes that occurred in surviving OHCs. The early course of the effects suggests that the effects were direct and not secondary to degeneration of other cells. In contrast to the rapid and striking cytochemical changes seen in type I fibrocytes, type III fibrocytes showed early and avid gentamicin uptake and prolonged immunostaining for gentamicin, but they were the most resistant cochlear cells to degeneration following treatment (see accompanying article). The present results indicate that type III fibrocytes showed little evidence of toxic reactions following gentamicin treatment. The contrasts of results with type I and type III fibrocytes make it clear that uptake and retention of gentamicin are not necessarily good predictors of toxic effects that may be produced thereby.

In most cases changes in cytochemical profiles of cells of the spiral ligament and spiral limbus occurred with a similar time course as those seen in OHCs. This suggests that the changes seen in the connective tissue cells were direct effects of the gentamicin and were not secondary to $\mathrm{OHC}$ changes. It is possible that interactions between cell classes contributed to some of the cytochemical changes that were observed following gentamicin treatment. For example, it has been found that hair cells in cochleas of guinea pigs with experimentally induced endolymphatic hydrops are more vulnerable to destruction by aminoglycosides than those in normal ears (Kimura et al. 1991). In hydropic guinea pigs, type I fibrocytes show many of the same cytochemical abnormalities as those found in the present study (Ichimiya et al. 1994b). This suggests that the added vulnerability of hair cells to gentamicin in hydropic guinea pigs may be associated with loss of type I fibrocyte function. Similarly, changes in type I fibrocyte function induced by gentamicin treatment, as evidenced by changes in cytochemical profiles, may have induced in other cells a vulnerability to gentamicin toxicity that would not have been present otherwise. It remains to be determined which changes were direct effects of the drug and which were indirect. 


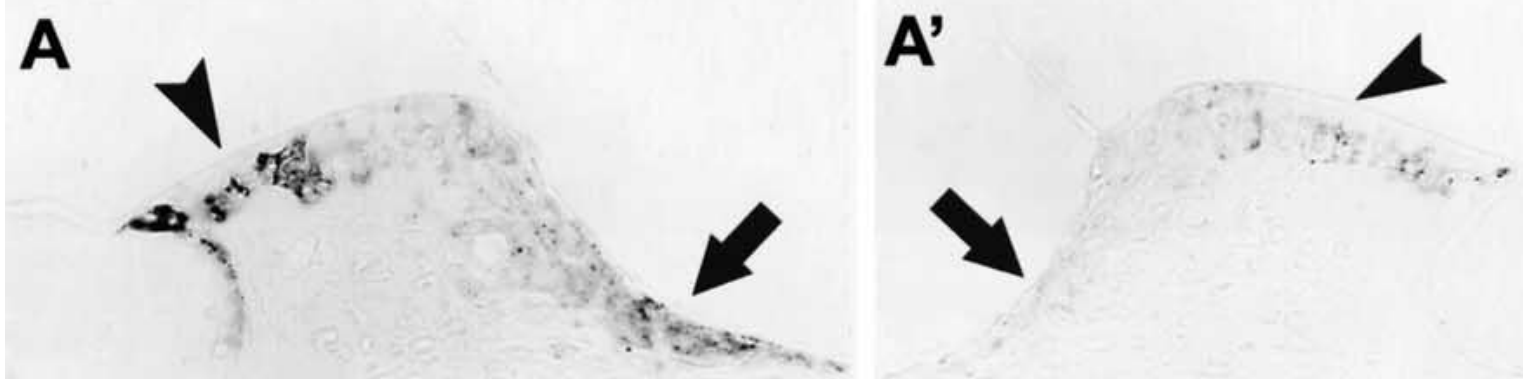

\section{SERCA1}

B

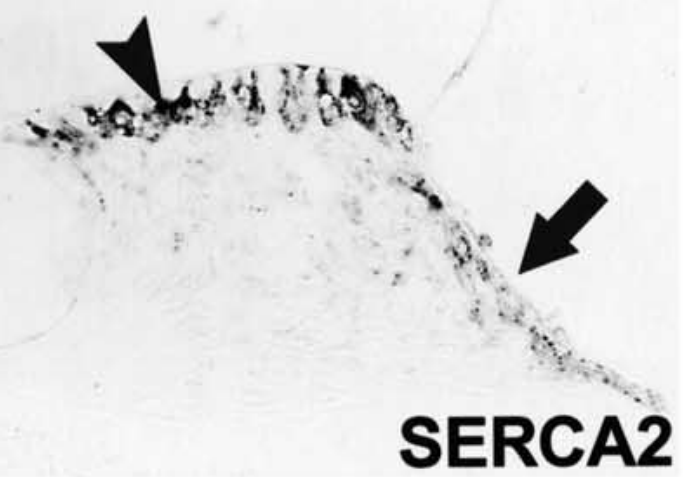

C

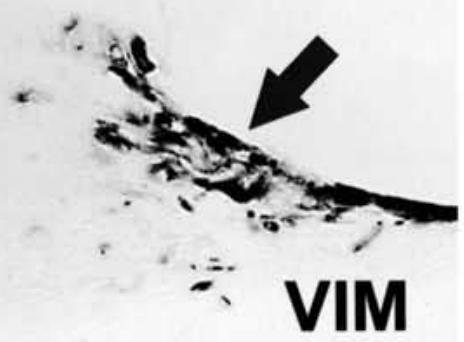

B'
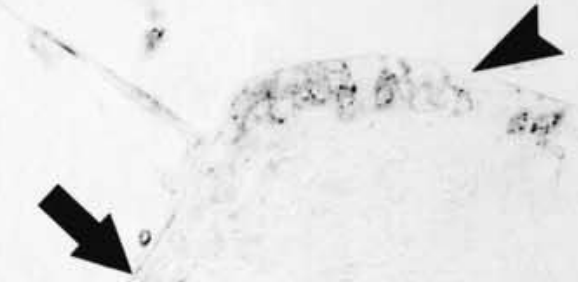

C'

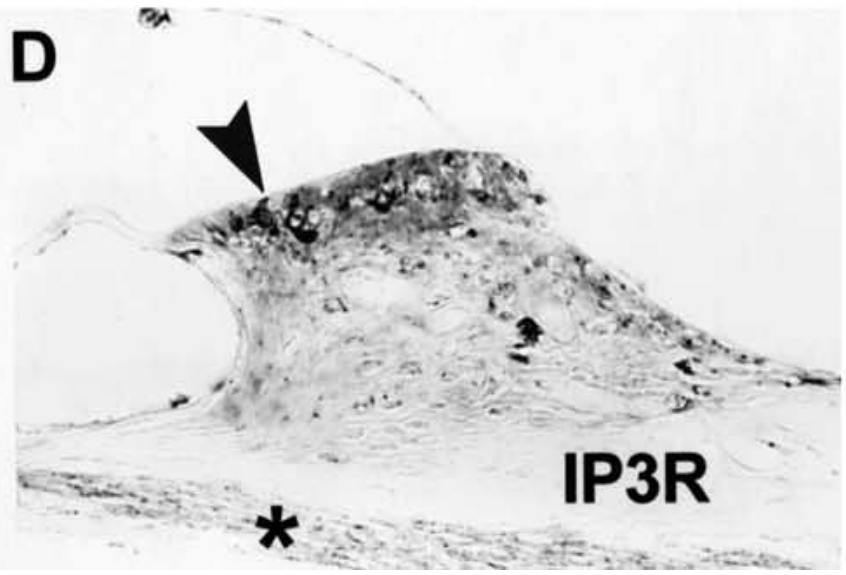

D'

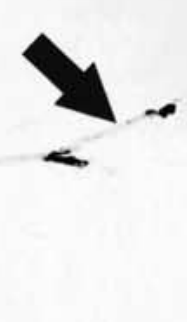




\section{Cytochemical effects of gentamicin treatment}

It has been reported that the enzymes $\mathrm{Na}^{+}, \mathrm{K}^{+}$-ATPase (Schulte and Adams 1989a; Spicer and Schulte 1991; Ryan and Watts 1991; Ichimiya et al. 1994a,b; Ten Cate et al. 1994) and CA (Hsu and Nomura 1985; Spicer and Schulte 1991; Okamura et al. 1996), which are involved in the regulation of intracellular and extracellular $\mathrm{Na}^{+}, \mathrm{K}^{+}, \mathrm{HCO}_{3}^{-}$, and $\mathrm{H}^{+}$ion levels, are abundant in a variety of cells within the cochlea. Calcium ions are known to be critically involved in a wide variety of cellular events. It is known that there are two general classes of ATP-driven $\mathrm{Ca}^{++}$pumps; they are present in the smooth endoplasmic reticulum and in the plasma membrane (Blaustein 1988). It has been reported that both cytosolic (Schulte 1993; Ichimiya et al. 1994a) and plasma membrane $\mathrm{Ca}^{++}$ ATPase (Yoshihara and Igarashi 1987; Crouch and Schulte 1995; Apicella et al. 1997; Curtis et al. 1997) are present in inner ear tissue where they regulate calcium-sensitive cellular processes. In the present study, the localization of three different plasma membrane $\mathrm{Ca}^{++}$-ATPases, as well as the $\mathrm{Na}^{+}, \mathrm{Ca}^{++}$exchanger, $\mathrm{Na}^{+}, \mathrm{K}^{+}$-ATPase, $\mathrm{CKBB}$, and $\mathrm{CA}$ was demonstrated. The $\mathrm{Na}^{+}, \mathrm{Ca}^{++}$exchanger was previously reported to be present in the cochlea (Oshima et al. 1997) but it was not localized to specific cells. The localization of CKBB in the spiral limbus has previously been reported (Spicer and Schulte 1991). CKBB facilitates transfer of high-energy phosphate from creatinine phosphate to ADP and may provide ATP to the above-mentioned energy-dependent ion transport mechanisms within the cochlea. It was included in this report to show that changes in its levels of staining did not precisely match that of any individual ATPase. The cellular levels of all of the above-mentioned enzymes, which very likely play key roles in active transport of ions in their respective cells, were found to be affected by the gentamicin treatment. Furthermore, the intermediate filament vimentin has been shown to be involved in response to tissue

FIG. 9. Changes in immunostaining of the spiral limbus (2). Interdental cells (arrowhead) located on the organ of Corti side in the spiral limbus and fibrocytes (arrow) in the supralimbal area of the control side $(\mathbf{A})$ are positive for SERCA1. There is decreased unmunostaining of both cell types on the treated side $\left(\mathbf{A}^{\prime}\right)$. Interdental cells (arrowhead) in the spiral limbus and fibrocytes (arrow) in the supralimbal area of the control side $(\mathbf{B})$ are immunoreactive for SERCA2. This staining is decreased on the treated side $\left(\mathbf{B}^{\prime}\right)$. Cells in the supralimbal area (arrow) of the control side $(\mathbf{C})$ are positive for the vimentin. Staining on the treated side $\left(\mathbf{C}^{\prime}\right)$ is decreased. Interdental cells (arrowhead) are immunostained for $I P_{3} R(D)$. On the treated side $\left(\mathbf{D}^{\prime}\right)$, a decrease in staining is apparent on the modiolar side of the limbus, but less change, if any, is present on the organ of Corti side (arrowhead). Survival times: $\mathbf{A}=3$ months, $\mathbf{B}=1$ month, $\mathbf{C}=6$ months. Scale bar in $\mathbf{A}=50 \mu \mathrm{m}$. damage (Oesterle et al. 1990; Calvo et al. 1991; Gallanti et al. 1992; SundarRaj et al. 1992; Usami et al. 1993) and has been reported to be present within the cochlea (Anniko et al. 1987; Schulte and Adams 1989b; Shi et al. 1993). Staining for vimentin was found to be changed in some cells in response to gentamicin treatment. Changes in the normal staining patterns for vimentin, particularly increases in staining, show that gentamicin affected cell systems other than ion-controlling systems.

A variety of calcium-binding proteins are known to be present in the inner ear where they are thought to play diverse roles in transduction, motile response, and in neurotransmitter release (Rabie et al. 1983; Dechesne et al. 1991; Flock et al. 1986; Slepecky and Ulfendahl 1993; Ichimiya et al. 1994a,b). The large number of calcium-binding proteins in the present study was included because their individual characteristic distributions suggest that they serve different functions within the cochlea (e.g., Pack and Slepecky 1995; Imamura and Adams 1996). Changes in these proteins and the calcium pumps were among the most sensitive indicators that gentamicin administration had affected individual cells. This suggests that control of intracellular calcium levels may be among the most vulnerable cellular functions that are subject to gentamicin disruption, regardless of cell type. Given the importance of calcium regulation for normal cellular function, dysregulation of calcium-controlling compounds would be expected to be quite disruptive to the affected cells. Perhaps the relative paucity of calcium-controlling proteins within type III fibrocytes is related to their extreme insensitivity to toxic effects of gentamicin. In contrast to calciumbinding and -pumping proteins, levels of $\mathrm{IP}_{3} \mathrm{R}$, which seems likely to play complementary roles to the calcium-binding proteins, were not found to be as reliable or sensitive an index of disruption, except in type I fibrocytes, where it is most abundant. Perhaps $\mathrm{IP}_{3} \mathrm{R}$ levels are controlled by different pathways than those of the presumed complementary proteins.

Hair cells. In this study, decreased immunostaining for PMCA of the stereocilia and the cuticular plate of OHCs in gentamicin-treated ears was striking. The restricted presence of PMCA in the stereocilia and cuticular plate of OHCs (Crouch and Schulte 1995; Apicella et al. 1997; Furuta et al. 1998; Takahashi and Kitamura 1999; Street et al. 1998) suggests that it may affect mechanoelectrical transduction through calcium ion regulation (see, e.g., Fettiplace et al. 2001). It seems reasonable to assume that surviving hair cells with greatly reduced PMCA levels were not functioning normally. This finding emphasizes the need for assays that are more informative than the mere presence of hair cells or other cochlear cells when 


\section{A}

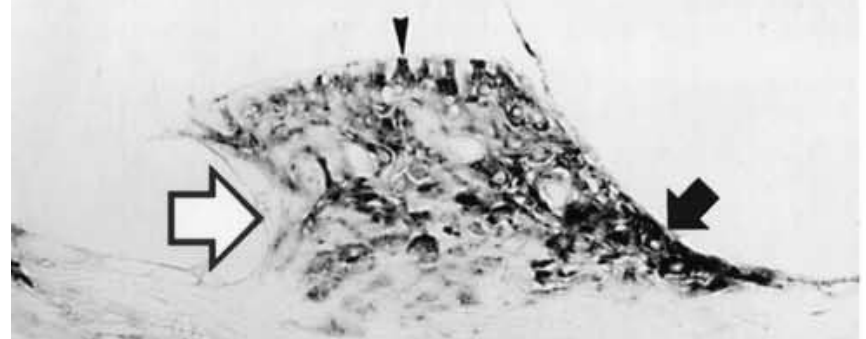

$A^{\prime}$

CaM
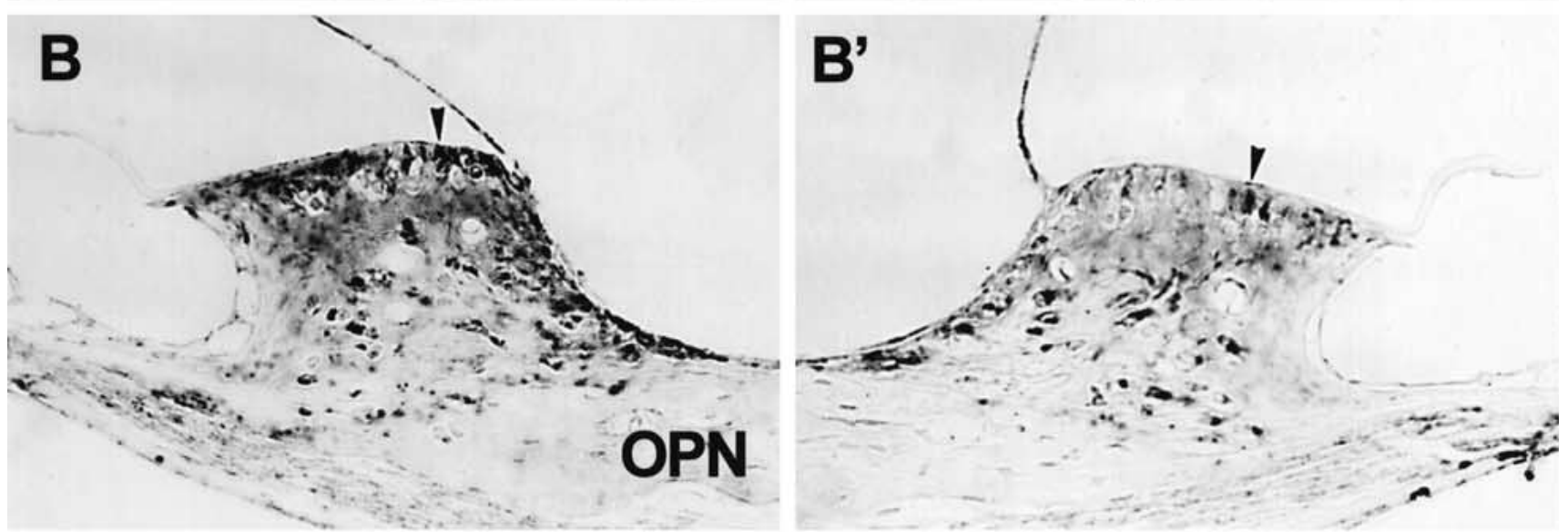

C

C'
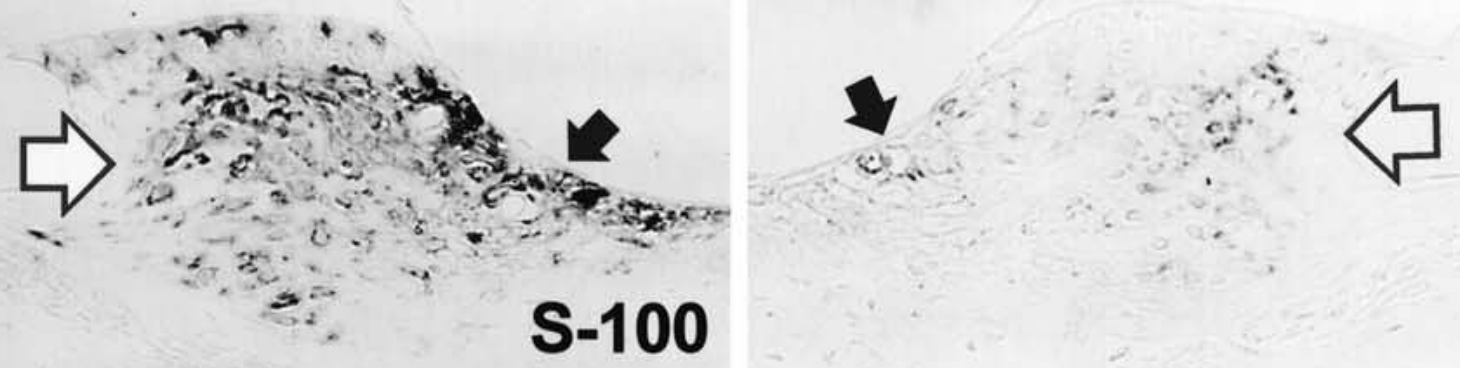

D

D'

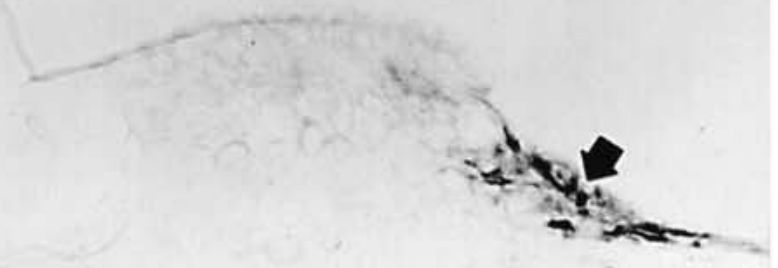


assessing effects of aminoglycosides or other treatments.

There was decreased immunostaining of nerve terminals of OHCs for $\mathrm{Na}^{+}, \mathrm{K}^{+}$-ATPase and 200kD neurofilaments. This may be related to results reporting an inhibition of the $\mathrm{K}^{+}$channel in single, isolated, efferent nerve terminals by aminoglycosides (Takeuchi and Wangemann 1993). On the other hand, the decreased immunostaining may simply reflect a loss of nerve terminals that followed degeneration of the organ of Corti, as indicated by loss of ganglion cells.

Spiral ganglion. Spiral ganglion cells were positive for $\mathrm{Na}^{+}, \mathrm{K}^{+}$-ATPase, PMCA, SERCA1, and SERCA2. These findings suggest the presence of multiple iondependent neural processes in spiral ganglion cells. Decreased immunostaining for $\mathrm{Na}^{+}, \mathrm{K}^{+}$-ATPase, PMCA, SERCA1, and SERCA2 in spiral ganglion cells was detected only in the animals with long survival periods (greater than 1 month). The decreased staining of ganglion cells for these enzymes indicates that the surviving ganglion cells were less active that those in normal ears. In an analysis of gentamicin uptake in this same material (see accompanying article), it was found that there was little uptake or retention of gentamicin by spiral ganglion cells. The limited gentamicin uptake, together with the long delay in cytochemical changes, indicates that the above-mentioned effects on spiral ganglion cells were secondary to hair cell destruction or disruption and not directly due to gentamicin toxicity. The decreases in staining of ganglion cells for the ion-transporting enzymes indicate that ganglion cells deprived of their normal trophic and sensory inputs downregulate these proteins. If this interpretation is correct, it implies that the 4-6 kHz tinnitus, which often accompanies aminoglycoside toxicity in humans (Quick 1981), is not the result of abnormally high activity of surviving ganglion cells. Physiological studies of eighth nerve activity in animals that were systemically

FIG. 10. Changes in immunostaining of the spiral limbus (basal turn) following local application of gentamicin. Fibrocytes (open arrow) in the spiral limbus, supralimbal cells (closed arrow), and interdental cells (arrowhead) of the control side (A) are immunoreactive for calmodulin. There is decreased staining of all these cells on the treated side $\left(\mathbf{A}^{\prime}\right)$. Fibrocytes in the spiral limbus and interdental cells (arrowhead) of the control side $(\mathbf{B})$ are immunoreactive for osteopontin. There is decreased staining on the treated side $\left(\mathbf{B}^{\prime}\right)$. Fibrocytes (open arrow) in the spiral limbus and supralimbal cells (closed arrow) of the control side $(\mathbf{C})$ are positive for S-100. There is decreased immunostaining of both cell types on the treated side $\left(\mathbf{C}^{\prime}\right)$. Supralimbal cells (arrow) of the control side (D) are positive for caldesmon. There is markedly decreased immunostaining on the treated side $\left(\mathbf{D}^{\prime}\right)$. The survival periods: $\mathbf{A}, \mathbf{B}=7$ days, $\mathbf{C}=1$ month, $\mathbf{D}=6$ months. Scale bar in $\mathbf{A}=50 \mu \mathrm{m}$. treated with aminoglycosides are in keeping with this interpretation (e.g., Kiang et al. 1970).

Spiral ligament. Recent immunochemical studies reported that a number of proteins involved in transport-related activity, including $\mathrm{Na}^{+}, \mathrm{K}^{+}$-ATPase (Schulte and Adams 1989a; Ichimiya et al. 1994a,b), CA (Spicer and Schulte 1991), CKBB (Spicer and Schulte 1991), and PMCA (Crouch and Schulte 1995; Curtis et al. 1997), are present within cells of the spiral ligament. Most or all cells within the spiral ligament are interconnected via a gap junctional network, a principal component of which is connexin 26. These cells are thought to be involved in the maintenance of ionic homeostasis in inner ear fluids (Kikuchi et al. 1995). In the present study, we found that SERCA1, SERCA2, and the $\mathrm{Na}^{+}, \mathrm{Ca}^{++}$exchanger are present in specific cells within the spiral ligament. The presence of SERCA2 within lateral wall tissue was previously reported based upon ELISA assays (Curtis et al. 1997). The presence of these proteins adds to the evidence that precise control of intracellular calcium level is critical for fibrocyte function, probably in the context of calcium as a second messenger. Types I and II fibrocytes of the spiral ligament were positive for a variety of ion transport-related proteins and for connexin 26 (see Table 2). This suggests that these fibrocytes play important roles in the maintenance of $\mathrm{Na}^{+}, \mathrm{K}^{+}, \mathrm{H}^{+}$, and $\mathrm{Ca}^{++}$ion levels of inner ear fluids. Decreased immunostaining for these proteins would be expected to reflect dysregulation of ionic content of inner ear fluids. Chronic administration of aminoglycosides has been reported to affect cation levels of the endolymph and to reduce the endolymphatic potential (Mendelsohn and Katzenberg 1972). Differences in experimental conditions between those findings and the present report do not permit direct comparisons, but it would be surprising if the changes in levels of ion-controlling proteins found in the present study did not reflect or perhaps result in widespread disruption of homeostatic mechanisms within the cochlea, including endolymph content.

Spiral limbus. The fibrocytes of the spiral limbus and supralimbal area, whose functions are not as well understood as those of the spiral ligament, were positive for various ion transport-related proteins and connexin 26, and all showed decreased immunostaining in treated ears. This suggests that their normal functions, whatever they are, were impeded following gentamicin treatment. Loss of limbal cells has previously been reported following aminoglycoside treatment, as well as following many other insults that may affect perilymph content (Kimura et al. 1990). This raises the possibility that malfunction of limbal cells could have contributed to toxic effects of gentamicin in the organ of Corti and other locations. 


\section{Implications for protective measures}

There are growing numbers of compounds that have been found to protect the cochlea from gentamicin toxicity (Yokota et al. 1989; Garetz et al. 1994; Xuan and Dong 1995; Song et al. 1998; Gao 1999; Sha and Schacht 1999; Suzuki et al. 2000; Sinswat et al. 2000; Pirvola et al. 2000). It is generally assumed that the protective effects of these compounds are due to direct effects upon hair cells. The present results indicate the need for confirming the site of actions of the protective compounds. In principle, the cytotoxic effects of gentamicin upon nonsensory cells reported herein may have additive effects with direct effects of gentamicin upon hair cells, just as in the case of the hydropic guinea pig (Kimura et al. 1991). If so, the compounds that afford protection from gentamicin toxicity may do so by blocking gentamicin effects upon nonsensory cells. It would be of considerable interest to determine which cochlear cells besides hair cells are protected by compounds that block gentamicin toxicity. Differential protection could provide a powerful means of selectively damaging given cell types for exploration of their functions.

\section{Clinical implications}

It seems possible that the effects found in so many cells and cell types in this animal model could occur in patients who are treated with local gentamicin for relief of debilitating vestibular symptoms. The progressive nature of the effects with post administration time suggests that there is progressive deterioration of the tissue. These findings suggest that patients treated with local applications of gentamicin for vestibular disorders could show little or no hearing loss soon after the treatment but that hearing losses may increase, progressing from high to lower frequencies, with increasing posttreatment times. The present results reinforce the importance of testing for hearing losses in such patients many months following gentamicin treatment in order to assess the extent to which hearing losses may progress.

\section{CONCLUSIONS}

The present results show that a variety of cochlear cells that survive local gentamicin treatment are either directly or indirectly affected by the treatment, as indicated by changes in their cytochemical profiles. The functional significance for most nonsensory cochlear cells remains largely unexplored but it seems safe to assume that none lack importance for cochlear integrity. The present expansion of the known scope of cytochemical profiles of these cells, along with evidence that these profiles are altered by local gentamicin treatment, should contribute toward a better conceptual framework for these cells' functions and perhaps inspire studies that will help develop that framework to incorporate these cells into a more comprehensive understanding of cochlear function and pathology.

\section{ACKNOWLEDGMENTS}

This work was supported by NIH grant DC 03929. The authors are grateful to M.C. Liberman, J.B. Nadol, Jr., and W.F. Sewell for helpful comments on the manuscript.

\section{REFERENCES}

ADAMS JC. Biotin amplification of biotin and horseradish peroxidase signals in histochemical stains. J. Histochem. Cytochem. 40:1457-1463, 1992.

Anniko M, Thornell L-E, Virtanen I. Cytoskeletal organization of the human inner ear. Acta Otolaryngol. Suppl. (Stockh.) 437: 29-54, 1987.

Apicella S, Chen S, Bing R, Penniston JT, Llinas R, Hillman DE. Plasmalemmal ATPase calcium pump localizes to inner and outer hair bundles. Neuroscience. 79:1145-1151, 1997.

Bareggi R, Grill V, Narducci P, Zweyer M, Tesei L, Russolo M. Gentamicin ototoxicity: histological and ultrastructural alterations after transtympanic administration. Pharmacol. Res. 22:635-644, 1990.

Berggren D, Anniko M, Ramaekers F, Virtanen I. Intermediate filament proteins in the embryonic inner ear of mice under normal conditions and after exposure to ototoxic drugs. Acta Otolaryngol. 109:57-65, 1990.

BLAustein MP. Calcium transport and buffering in neurons. Trends Neurosci. 11:438-443, 1988.

Calvo JL, Carbonell AL, Boya J. Co-expression of glial fibrillary acidic protein and vimentin in reactive astrocytes following brain injury in rats. Brain Res. 566:333-336, 1991.

Cohn ES, Kelley PM. Clinical phenotype and mutations in connexin 26 (DFNB1/GJB2), the most common cause of childhood hearing loss. Am. J Med. Genet. 89:130-136, 1999.

Crouch JJ, Schulte BA. Expression of plasma membrane Ca-ATPase in the adult and developing gerbil cochlea. Hear. Res. 92:112-119, 1995.

Curtis LM, Garg LC, Rarey KE. Ca(2+)-ATPases in the cochlear duct. Acta Otolaryngol. 117:553-558, 1997.

Dallos P, Harris D. Properties of auditory nerve responses in absence of outer hair cells. J. Neurophysiol. 41:365-383, 1978.

Davis H, Deatherage BH, Rosenblut B, Fernandez C, Kimura RS, Sмiтн CA. Modification of cochlear potentials produced by streptomycin poisoning and by extensive venous obstruction. Laryngoscope. 68:596-627, 1958.

DeGroot J CMJ, Huzing EH, Veldman JE. Early ultrastructure effect of gentamicin cochleotoxicity. Acta Otolaryngol. 11:173$280,1991$.

Dechesne CJ, Winsky L, Kim HN, Goping G, Vu TD, Wenthold RJ, JACOBWITZ DM. Identification and ultrastructural localization of a calretinin-like calcium-binding protein (protein 10) in the guinea pig and rat inner ear. Brain Res. 560:139-148, 1991.

Fettiplace R, Ricci AJ, Hackney CM. Clues to the cochlear amplifier from the turtle ear. Trends Neurosci. 24:169-175, 2001. 
Flock Å, Flock B, Ulfendahl M. Mechanisms of movement in outer hair cells and possible structural basis. Arch. Otorhinolaryngol. 243:83-90, 1986.

Forge A, Fradis M. Structural abnormalities in the stria vascularis following chronic gentamicin treatment. Hear. Res. 20:233-244, 1985.

Forge A, Schacht J. Aminoglycoside antibiotics. Audiol. Neurootol. 5:3-22, 2000.

Furuta H, Luo L, Hepler K, Ryan AF. Evidence for differential regulation of calcium by outer versus inner hair cells: plasma membrane Ca-ATPase gene expression. Hear. Res. 123:10-26, 1998.

Gallanti A, Prelle A, Moggio M, Ciscato P, Checcarelli N, Sciacco M, Comini A, Scarato G. Desmin and vimentin as markers of regeneration in muscle diseases. Acta Neuropathol. 85:88-92, 1992.

GAO WQ. Role of neurotrophins and lectins in prevention of ototoxicity. Ann. N. Y. Acad. Sci. 884:312-327, 1999.

Garetz SL, Altschuler RA. Attenuation of gentamicin ototoxicity by glutathione in the guinea pig in vivo. Hear. Res. 77:81-87, 1994.

HaWkins JE JR, Johnsson LG. Histopathology of cochlear and vestibular ototoxicity in laboratory animals. In: Lerner SA, Mats GJ, Hawkins Jr JE (eds) Aminoglycoside Ototoxicity. Little, Brown, Boston, 1981, pp 175-195

Hsu CJ, Nomura Y. Carbonic anhydrase activity in the inner ear. Acta Otolaryngol. Suppl. 418:1-42, 1985.

Husmann KR, Morgan AS, Girod DA, Durham D. Round window administration of gentamicin: a new method for the study of ototoxicity of cochlear hair cells. Hear. Res. 125:109-119, 1998.

ICHimiYa I, AdAms JC, KimuRa RS. Immunolocalization of $\mathrm{Na}^{+}, \mathrm{K}^{+}$ATPase, $\mathrm{Ca}^{++}$-ATPase, calcium-binding proteins, and carbonic anhydrase in the guinea pig inner ear. Acta Otolaryngol. (Stockh.) 114:167-176, 1994a.

ICHIMIYA I, AdAMS JC, Kimura RS. Changes in immunostaining of cochleas with experimentally induced endolymphatic hydrops. Ann. Otol. Rhinol. Laryngol. 103:457-468, 1994b.

ImAMURA S, AdAMS JC. Immunolocalization of peptide 19 and other calcium-binding proteins in the guinea pig cochlea. Anat. Embryol. 194:407-418, 1996.

Kelsell DP, Dunlop J, Hodgins MB. Human diseases: clues to cracking the connexin code? Trends Cell. Biol. 11:2-6, 2001.

KIANG NY, Moxon EA, Levine RA. Auditory-nerve activity in cats with normal and abnormal cochleas. In: Wolstenholme GEW, Knight J (eds) Ciba Foundation Symposium on Sensorineural Hearing Loss. Churchhill, London, 1970, pp 241-273

Kiang NY, Liberman MC, Levine RA. Auditory-nerve activity in cats exposed to ototoxic drugs and high-intensity sounds. Ann. Otol. Rhinol. Laryngol. 85:752-768, 1976.

KikUChi T, Kimura RS, AdAms JC. Gap junctions in the rat cochlea: Immunohistochemical and ultrastructural analysis. Anat. Embryol. 191:101-118, 1995.

Kikuchi T, Kimura RS, Paul DL, Takasaka T, Adams J. Gap junction systems in the mammalian cochlea. Brain Res. Brain Res. Rev. 32:163-166, 2000.

Kimura RS, Iverson NA, Southard RE. Selective lesions of the vestibular labyrinth. Ann. Otol. Rhinol. Laryngol. 97:577-584, 1988.

Kimura RS, NyE CL, Southard RE. Normal and pathologic features of the limbus spiralis and its functional significance. Am. J. Otolaryngol. 11:99-111, 1990.

Kimura RS, Lee K-S, Nye CL, Trehey JA. Effects of systemic and lateral semicircular canal administration of aminoglycosides on normal and hydropic inner ears. Acta Otolaryngol. (Stockh.) 111:1021-1030, 1991.

Komune S, SNOw JB. Nature of the endocochlear dc potential kanamicin-poisoned guinea pigs. Arch. Otolaryngol. 108:334-338, 1982.
Konishi T. Effects of local application of ototoxic antibiotics on cochlear potential in guinea pigs. Acta Otolaryngol. 88:41-46, 1979.

Kuno M, Gardner P. Ion channels activated by inositol 1,4,5-triphosphate inplasma membrane of human T-lymphocytes. Nature. 326:301-304, 1987.

Mendelsohn M, Katzenberg I. The effect of kanamicin on the cation content of the endolymph. Laryngoscope. 82:397-402, 1972.

Nakashima T, Teranishi M, Hibi T, Kobayashi M, Umemura M. Vestibular and cochlear toxicity of aminoglycosides-a review. Acta Otolaryngol. 120:904-911, 2000.

Oesterle EC, Sarthy PV, Rubel EW. Intermediate filaments in the inner ear of normal and experimentally damaged guinea pigs. Hear. Res. 47:1-16, 1990.

Okamura H-O, Sugai N, Suzuki K, Ohtani I. Enzyme-histochemical localization of carbonic anhydrase in the inner ear of the guinea pig and several improvements of the technique. Histochem. Cell Biol. 106:425-430, 1996.

Oshima T, Ikeda K, Furukawa M, Takasaka T. Alternatively spliced isoforms of the $\mathrm{Na}^{+} / \mathrm{Ca}^{2+}$ exchanger in the guinea pig cochlea. Biochem. Biophys. Res. Commun. 233:737-741, 1997.

PACK AK, SLePeCKY NB. Cytoskeletal and calcium-binding proteins in the mammalian organ of Corti: cell type-specific proteins displaying longitudinal and radial gradients. Hear. Res. 91:119$135,1995$.

Pirvola U, Xing-Qun L, Virkkala J, Saarma M, Murakata C, Camoratto A, WaLton K, Ylikoski J. Rescue of hearing, auditory hair cells, and neurons by CEP-1347/KT7515, an inhibitor of c-Jun N-terminal kinase activation. J. Neurosci. 20:43-50, 2000.

Quick C. Ototoxic interactions between aminoglycosides and loop diuretics in man. In: Lerner SA, Mats GJ, Hawkins Jr JE (eds) Aminoglycoside Ototoxicity. Little, Brown, Boston, 1981, pp 373-384

Rabie A, Thomasset M, Legrand CC. Immunocytochemical detection of calcium-binding protein in the cochlear and vestibular hair cells of the rat. Cell. Tissue Res. 232:691-696, 1983.

RyAN AF, WATTS AG. Expression of mRNA encoding $\alpha$ and $\beta$ subunit isoforms of the $\mathrm{Na}^{+}, \mathrm{K}^{+}$-ATPase in the rat cochlea. Mol. Cell. Neurosci. 2:179-187, 1991.

Santi PA, Ruggero MA, Nelson DA, Turner CW. Kanamycin and bumetanide ototoxicity: anatomical, physiological and behavioral correlates. Hear. Res. 7:261-279, 1982.

SCHMiedt RA, Zwislocki JJ, Hamernik RP. Effects of hair cell lesions on responses of cochlear nerve fibers. I. Lesions, tuning curves, two-tone inhibition, and responses to trapezoidal-wave patterns. J. Neurophysiol. 43:1367-1389, 1980.

Schulte BA, Adams JC. Distribution of immunoreactive $\mathrm{Na}^{+}, \mathrm{K}^{+}$ATPase in gerbil cochlea. J. Histochem. Cytochem. 37:127-134, 1989a.

Schulte BA, Adams JC. Immunohistochemical localization of vimentin in the gerbil inner ear. J. Histochem. Cytochem. 37:1787-1797, 1989b.

Schulte BA. Immunohistochemical localization of intracellular CaATPase in outer hair cells, neurons and flbrocytes in the adult and developing inner ear. Hear. Res. 65:262-273, 1993.

Sha SH, ZaJic G, Epstein CJ, Schacht J. Overexpression of copper/ zinc-superoxide dismutase protects from kanamycin-induced hearing loss. Audiol. Neurootol. 6:117-123, 2001.

Shi S-R, Tandon AK, Haussmann RRM, Kalra KL, Taylor CR. Immunohistochemical study of intermediate filament proteins on routinely processed celloidin embedded human temporal bone sections by using a new technique for antigen retrieval. Acta Otolaryngol. (Stockh.) 113:48-54, 1993.

Sinswat P, Wu WJ, Sha SH, Schacht J. Protection from ototoxicity of intraperitoneal gentamicin in guinea pig. Kidney Int. 58:2525-2532, 2000. 
SLEPECKY NB, UlfENDAHL M. Evidence for calcium-binding proteins and calcium-dependent regulatory proteins in sensory cells of the organ of Corti. Hear. Res. 70:73-84, 1993.

Song BB, Sha SH, Schacht J. Iron chelators protect from aminoglycoside-induced cochleo- and vestibulo-toxicity. Free Radic. Biol. Med. 25:189-195, 1998.

Spicer SS, Schulte BA. Differentiation of inner ear fibrocytes according to their ion transport related activity. Hear. Res. 56:5364, 1991.

Street V, McKee-Johnson J, Fonseca R, Tempel B, Noben-Trauth K. Mutations in a plasma membrane $\mathrm{Ca}^{2+}$-ATPase gene cause deafness in deafwaddler mice. Nat. Genet. 19:390-394, 1998.

SundarRaj N, Rizzo JD, Anderson SC, Gesitto JP. Expression of vimentin by rabbit corneal epithelial cells during wound repair. Cell Tissue Res. 267:347-356, 1992.

Suzuki M, Yagi M, Brown JN, Miller AL, Miller JM, Raphael Y. Effect of transgenic GDNF expression on gentamicin-induced cochlear and vestibular toxicity. Gene Ther. 7:1046-1054, 2000.

Ten Cate WF, Curtis LM, Rarey KE. $\mathrm{Na}^{+}, \mathrm{K}^{+}$-ATPase $\alpha$ and $\beta$ subunit isoforms distribution in the rat cochlea and vestibular tissues. Hear. Res. 75:151-160, 1994.

Takahashi K, Kitamura K. A point mutation in a plasma membrane $\mathrm{Ca}(2+)$-ATPase gene causes deafness in Wriggle Mouse Sagami. Biochem. Biophys. Res. Commun. 261:773-778, 1999.
Takeuchi S, Wangemann P. Aminoglycoside antibiotics inhibit maxi- $\mathrm{K}^{+}$channel in single isolated cochlear efferent nerve terminal. Hear. Res. 67:13-19, 1993.

Usami S-I, Hozawa J, Shinkawa H, Saito S-I, Matsubara A, Fujita S. Immunocytochemical localization of intermediate filament in the guinea pig vestibular periphery with special reference to their alteration after ototoxic drug administration. Acta Otolaryngol. Suppl. (Stockh.) 506:7-13, 1993.

Wanamaker HH, Slepecky NB, Cefaratti LK, Ogata Y. Comparison of vestibular and cochlear ototoxicity from transtympanic streptomycin administration. Am. J. Otol. 20:457-464, 1999.

Wersall J. Ototoxic antibiotics: a review. Acta Otolaryngol. Suppl. 519:26-29, 1995.

Worley PF, Baraban JM, Colvin JS, SNyder SH. Inositol triphosphate receptor localization in brain: variable stoichiometry with protein kinase C. Nature 325:159-161, 1987.

Xuan W, Dong M. Effects of compound injection of Pyrola rotundifolia. L. and Astragalus membranaceus Bge on experimental guinea pigs' gentamicin ototoxicity. Ann. Otol. Rhinol. Laryngol. 104:374-380, 1995.

Yokota M, NiIzato T, Inouye S, Kitasato I. Effect of glucarolactam on ototoxicity of aminoglycoside antibiotics in guinea-pigs. Drugs Exp. Clin. Res. 15:261-272, 1989.

Yoshinara T, Igarashi M. Cytochemical localization of $\mathrm{Ca}^{++}$-ATPase activity in the lateral cochlear wall of the guinea pig. Arch. Otorhinolaryngol. 243:395-400, 1987. 